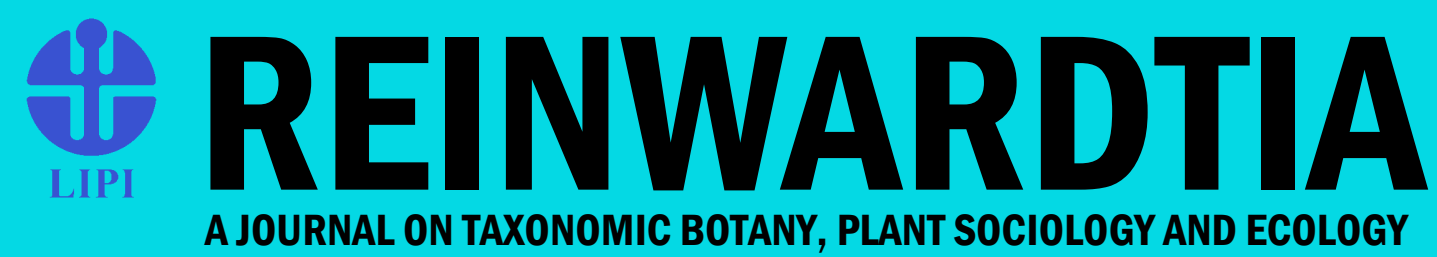

ISSN 0034 - 365 X | E-ISSN 2337 - 8824 | Accredited 792/AU3/P2MI-LIPI/04/2016
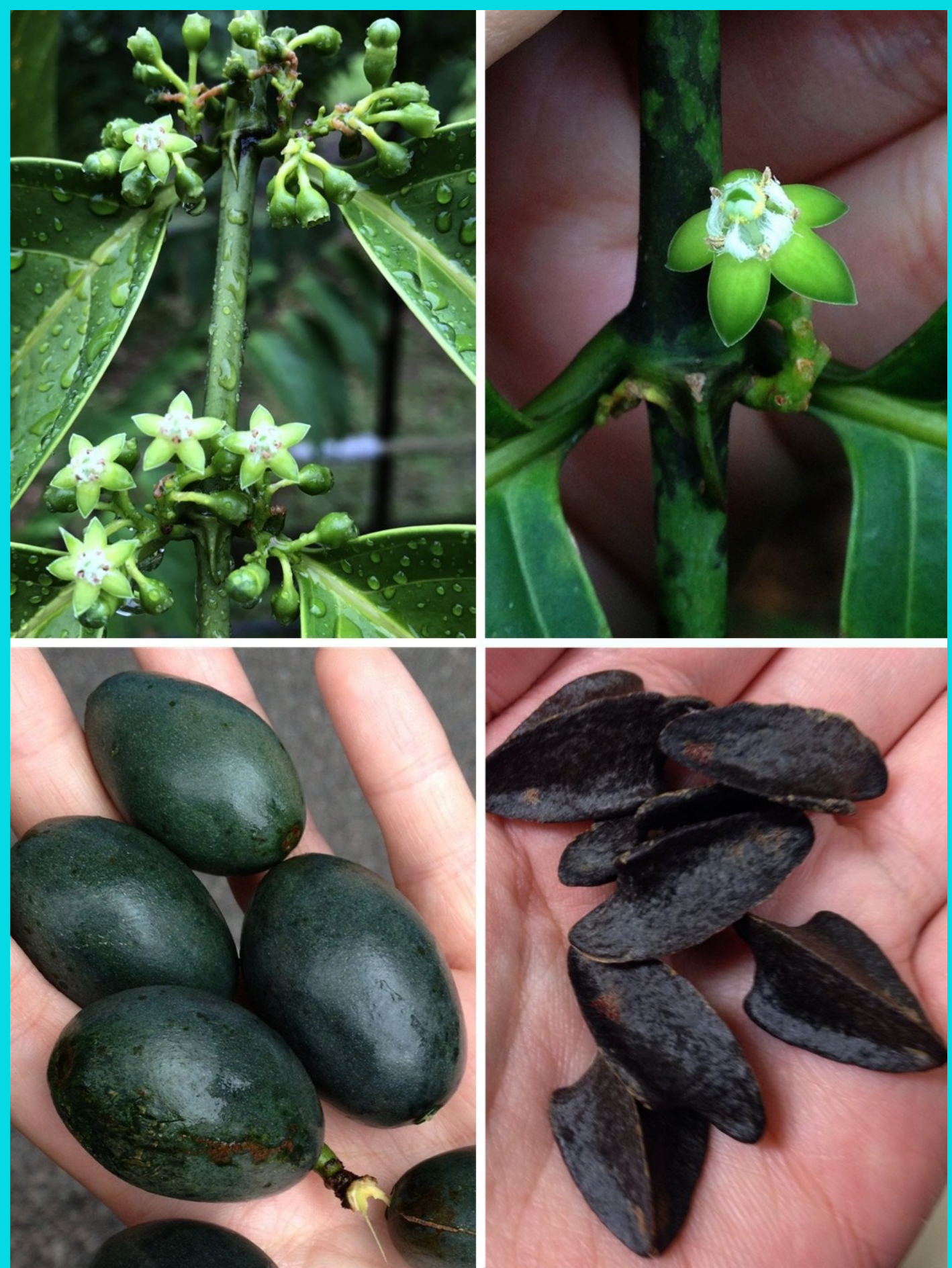

$201817(2)$ 


\section{REINWARDTIA}

\section{A JOURNAL ON TAXONOMIC BOTANY, PLANT SOCIOLOGY AND ECOLOGY}

Vol. 17 (2): 87 - 154, December 18, 2018

\section{Chief Editor}

Kartini Kramadibrata (Mycologist, Herbarium Bogoriense, Indonesia)

\section{Editors}

Dedy Darnaedi (Taxonomist, Herbarium Bogoriense, Indonesia)

Tukirin Partomihardjo (Ecologist, Herbarium Bogoriense, Indonesia)

Joeni Setijo Rahajoe (Ecologist, Herbarium Bogoriense, Indonesia)

Marlina Ardiyani (Taxonomist, Herbarium Bogoriense, Indonesia)

Himmah Rustiami (Taxonomist, Herbarium Bogoriense, Indonesia)

Lulut Dwi Sulistyaningsih (Taxonomist, Herbarium Bogoriense, Indonesia)

Topik Hidayat (Taxonomist, Indonesia University of Education, Indonesia)

Eizi Suzuki (Ecologist, Kagoshima University, Japan)

Jun Wen (Taxonomist, Smithsonian Natural History Museum, USA)

Barry J. Conn (Taxonomist, School of Life and Environmental Sciences, The University of Sydney, Australia)

David G. Frodin (Taxonomist, Royal Botanic Gardens, Kew, United Kingdom)

Graham Eagleton (Wagstaffe, NSW, Australia)

\section{Secretary}

Ruslan Bukhori

\section{Layout}

Liana Astuti

\section{Illustrators}

Subari

Wahyudi Santoso

Anne Kusumawaty

Correspondence on editorial matters and subscriptions for Reinwardtia should be addressed to:

HERBARIUM BOGORIENSE, BOTANY DIVISION,

RESEARCH CENTER FOR BIOLOGY - INDONESIAN INSTITUTE OF SCIENCES

CIBINONG SCIENCE CENTER, JLN. RAYA JAKARTA - BOGOR KM 46,

CIBINONG 16911, P.O. Box 25 CIBINONG

INDONESIA

PHONE (+62) 21 8765066; Fax (+62) 218765062

E-MAIL: reinwardtia@mail.lipi.go.id

http://e-journal.biologi.lipi.go.id/index.php/reinwardtia

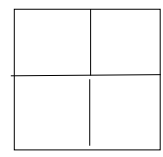

Cover images: Canthiumera robusta K.M.Wong \& X.Y.Ng, spec. nov. Top left: leafy branch with inflorescences; note also keeled stipules. Top right: flower with tufts of pale moniliform hairs visible opposite corolla lobes. Below left: fruits. Below right: pyrenes. Photos: Ang Wee Foong (top left) and X.Y. Ng (remaining images). 
The Editors would like to thank all reviewers of volume 17(2):

Andrew Powling, School of Biological Sciences, University of Portsmouth, Portsmouth, United Kingdom George Argent, Royal Botanic Garden Edinburgh, Edinburgh, United Kingdom

Joan Pereira, Forest Research Centre, Sandakan, Sabah, Malaysia

Jun Yokoyama, Dept. of Biology, Faculty of Science, Yamagata University, Yamagata, Japan

Khoon Meng Wong, Singapore Botanic Gardens, Singapore

Kongkanda Chayamarit, Queen Sirikit Botanic Garden, P.O. Box 7, Mae Rim, Chiang Mai, Thailand 


\title{
FLORA OF SINGAPORE PRECURSORS, 8. SYSTEMATY OF THE NEW SOUTHEAST ASIAN GENERA CANTHIUMERA AND DIBRIDSONIA (RUBIACEAE: VANGUERIEAE), WITH NOTES ON PLANT ARCHITECTURE AND REPRODUCTIVE ECOLOGY
}

Received June 28, 2018; accepted September 20, 2018

\section{K. M. WONG}

Singapore Botanic Gardens, National Parks Board, 1 Cluny Road, Singapore 259569. Email: wkm2000@gmail.com

\section{RIDHA MAHYUNI}

Herbarium Bogoriense, Botany Division, Research Center for Biology-LIPI, Cibinong Science Center, Jln. Raya Jakarta-Bogor Km. 46, Cibinong, 16911, Bogor, Indonesia.Email: ridhamahyuni@gmail.com

\section{XIN YI NG}

Native Plant Centre, Horticulture \& Community Gardening Division, National Parks Board, 100K Pasir Panjang Road, Singapore 118526.Email:ng_xin_yi@nparks.gov.sg

\section{LOUISE NEO}

Department of Biological Sciences, National University of Singapore, 14 Science Drive 4, Singapore 117543. Email: neolouise@gmail.com

\begin{abstract}
WONG, K. M., MAHYUNI, R., NG, X. Y. \& NEO, L. 2018. Flora of Singapore Precursors, 8. Systematy of the new Southeast Asian genera Canthiumera and Dibridsonia (Rubiaceae: Vanguerieae), with notes on plant architecture and reproductive ecology. Reinwardtia 17(2): 101-124. - The recognition of a number of distinct genera by morphological and molecular phylogenetic attributes from the Canthium s.l. complex still leaves a core group of morphologically disparate taxa. The distinguishing features of the spiny Canthium s.s. and two groups of non-spinescent Southeast Asian tree taxa still commonly identified with C. glabrum Blume and C. confertum Korth. are assessed against those of Cyclophyllum Hook.f., Bullockia (Bridson) Razafim., Lantz \& B.Bremer, Kanapia Arriola \& Alejandro, Keetia E.Phillips, Perakanthus Robyns ex Ridl., Psydrax Gaertn., and Pyrostria Comm. ex Juss., similarly arborescent genera that have been so distinguished through recent studies. Canthium glabrum and C. confertum are, respectively, the bases of the genera Canthiumera K.M.Wong \& Mahyuni and Dibridsonia K.M.Wong newly described here. The new species Canthiumera robusta K.M.Wong \& X.Y.Ng is described; new nomenclatural combinations include $C$. glabra (Blume) K.M.Wong \& Mahyuni, C. neilgherrensis (Wight) K.M.Wong, C. neilgherrensis var. chartacea (Gamble) K.M.Wong, C. siamensis (K.Schum.) K.M.Wong, Dibridsonia conferta (Korth.) K.M.Wong, D. culionensis (Elm.) K.M.Wong, and D. oblongifolia (Quisumb. \& Merr.) K.M.Wong. Canthium glabrum var. pedunculatum Pitard, Plectronia neilgherrensis var. chartacea Gamble and Canthium confertum Korth. are lectotypified. Plectronia viridis Merr. and P. leytensis Merr. are reduced to synonymy under Dibridsonia conferta. Notes on the tree architecture, dispersal ecology and germination of Canthiumera and Dibridsonia are provided.
\end{abstract}

Key words: Borneo, Canthium complex, corolla hairs, dispersal ecology, India, Indochina, Java, Malay Peninsula, Malesia, moniliform hairs, Philippines, pyrene, Sumatra, Thailand, tree architecture.

\begin{abstract}
ABSTRAK
WONG, K.M., MAHYUNI, R., NG, X.Y. \& NEO, L. 2018. Prekursor Flora Singapura, 8. Sistematika marga baru dari Asia Tenggara Canthiumera dan Dibridsonia (Rubiaceae: Vanguerieae), dengan catatan arsitektur pohon dan ekologi reproduktif. Reinwardtia 17(2): 101-124. - Pengenalan sejumlah marga secara morfologi dan filogenetik molekuler dari komplek Canthium s.l. masih menyisakan kelompok taksa dengan morfologi berbeda. Perbedaan ciriciri khas Canthium s.s. yang berduri dan juga dua kelompok pohon tanpa duri yang tersebar di Asia Tenggara umumnya masih diidentifikasi dengan nama $C$. glabrum Blume and $C$. confertum Korth. kini dibandingkan dengan marga Cyclophyllum Hook.f., Bullockia (Bridson) Razafim., Lantz \& B.Bremer, Kanapia Arriola \& Alejandro, Keetia E.Phillips, Perakanthus Robyns ex Ridl., Psydrax Gaertn., and Pyrostria Comm. ex Juss., yang merupakan marga yang sama-sama berperawakan pohon dibedakan melalui studi terbaru. Canthium glabrum dan C. confertum masing-masing merupakan dasar dari marga baru Canthiumera K.M.Wong \& Mahyuni dan Dibridsonia K.M.Wong disajikan disini. Jenis baru Canthiumera robusta K.M.Wong \& X.Y.Ng dipaparkan; kombinasi nomeklatur baru termasuk C. glabra (Blume) K.M.Wong \& Mahyuni, C. neilgherrensis (Wight) K.M.Wong, C. neilgherrensis var. chartacea (Gamble) K.M.Wong, C. siamensis (K.Schum.) K.M.Wong, Dibridsonia conferta (Korth.) K.M.Wong, D. culionensis (Elm.) K.M.Wong, and D. oblongifolia (Quisumb. \& Merr.) K.M.Wong. Lektotipe dipilih untuk Canthium glabrum var. pedunculatum Pitard, Plectronia neilgherrensis var. chartacea Gamble dan Canthium confertum Korth. Plectronia viridis Merr. dan P. leytensis Merr. dijadikan sinonim Dibridsonia conferta. Catatan tentang arsitektur pohon, ekologi penyebaran dan perkecambahan Canthiumera dan Dibridsonia disajikan.
\end{abstract}

Kata kunci: Arsitektur pohon, Borneo, ekologi pemencaran, Filipina, India, Indochina, Jawa, komplek Canthium, Malesia, piren, rambut moniliform, rambut pada mahkota, Semenanjung Malaysia, Sumatra, Thailand. 


\section{INTRODUCTION}

\section{TAXONOMIC HISTORY OF THE CANTHIUM COMPLEX AND SCOPE OF THE PRESENT WORK}

Canthium s.l. has been, and still is, an heterogeneous assemblage of genera (Bridson, 1985; 1992; Wong, 1988; 1989; Lantz \& Bremer, 2004; Razafimandimbison et al., 2009). Following the narrowing of the type alliance of Canthium Lam. to spiny trees or shrubs, scramblers and climbing taxa found in India and Sri Lanka (type provenances) as well as Africa (including Madagascar) and Southeast Asia by Bridson (1985; 1992) and Wong (1988; 1989), various non-spiny, mainly arborescent taxa previously identified with Canthium s.l. and allies have been allocated to or confirmed as other genera. For example, Psydrax Gaertn. has been reinstated as a genus distributed from Africa (Bridson, 1985) to South and Southeast Asia (Bridson, 1985; Wong 1988; 1989; Ridsdale, 1998; Arriola \& Alejandro, 2013; Mahyuni et al., 2018; Wong \& Mahyuni, 2018) as well as East Asia (Chen et al., 2011). Also, Keetia E.Phillips was again recognized for tropical and southern Africa (Bridson, 1986); Pyrostria Comm. ex Juss. was recircumscribed (Bridson, 1987) and augmented (Davis et al., 2007; Razafimandimbison et al., 2007; Alejandro et al., 2014; Arriola et al., 2015; 2016a); Afrocanthium (Bridson) Lantz \& B.Bremer was elevated to generic status (Lantz \& Bremer, 2004); still other species first named as Canthium were transferred to the related Cyclophyllum Hook.f. (Davis \& Ruhsam, 2005); and Bullockia (Bridson) Razafim., Lantz \& B. Bremer was more precisely delimited as a distinct genus (Razafimandimbison et al., 2009). More recently, Arriola et al. (2016b) described Kanapia Arriola \& Alejandro, a genus in this taxonomic complex restricted to the Philippines.

Genera such as Psydrax, Cyclophyllum and others in the Canthium alliance were clearly distinguished from a 'spiny group' including Canthium s.s. in the combined analysis using molecular (ITS and $\operatorname{trn} T-F$ sequences) and 30 morphological characters by Lantz \& Bremer (2004). Furthermore, Razafimandimbison et al. (2009), analysing sequence data from two nuclear (ETS and ITS) regions, were able to confirm that Peponidium (Baill.) Arènes was indeed a distinct genus accommodating all Comorean, Malagasy, and Seychellean 'Canthium' species (Razafimandimbison et al., 2007), and that Pyrostria included Leroya Cavaco, Neoleroya Cavaco, Pseudopeponidium Homolles ex Arènes, and Scyphochlamys Balf.f. For the first time also, the analyses of Razafimandimbison et al. (2009) indicated that the Southeast Asian Canthium confertum Korth. (placed by Bridson (1987) in her Group IV of Pyrostria s.l. and allies) was closely allied to Cyclophyllum. Thus the dismemberment and realignment of the Canthium complex has continued to this day.

What has emerged is that there are good morphological distinctions among the genera or clusters of genera. The Canthium s.s. group (including the type, Canthium parviflorum Lam. = C. coromandelicum (Burm.f.) Alston) can be distinguished by its mostly scrambling and climbing habit, axillary spines developing from supernumerary axillary buds, and flowers that are solitary, fasciculate or in cymes (Bridson 1985; 1992). The flowers or inflorescences are characteristically borne in the axils of leaves on normal shoots (developing elongate internodes), as well as in the axils of both normal leaves and scale- or bract-like reduced leaves found on axillary short-shoots ('brachyblasts', with internodes condensed into a very short axis) (Wong, 1988; 1989). Compared against this, all the other mostly arborescent members of the Canthium complex are unarmed, do not have supernumerary axillary buds or produce brachyblasts, and have flowers in clearly branched to sub-umbellate cymes. In this paper, we address the key morphological distinction of two groups of arborescent Southeast Asian taxa aberrant within Canthium that have been commonly identified with $C$. glabrum Blume and $C$. confertum Korth., and propose them as new genera after comparison with other superficially similar generic elements identified so far.

\section{MATERIALS AND METHODS}

This study was carried out using conventional approaches for herbarium taxonomic studies. Specimens at the BKF, BO, BRUN, K, KEP, L, P, SAN, SAR, SING and VNM herbaria (acronyms follow Thiers continuously updated) were examined. In addition, JSTOR images of type specimens and specimen catalogues at BM, K, L, P and SING were also checked. We acknowledge that this contribution is a continuing, morphologically based, taxonomic resolution to be considered in light of the situation that molecular phylogenetic analyses will only provide finer resolution of the Canthium complex in Southeast Asia, against the challenges of comprehensive taxon sampling and gaining additional insights from additional gene regions, in due time.

Several characters discussed in past workssuch as stipule form, flower sexuality, presence of a tubular part of the calyx limb, the form of the anther connective on its dorsal side, and fruit shape-have been excluded either because they are basically uninformative or have not been sufficiently well-documented or represented in specimen material. The characters in this survey 
(Table 1) thus include plant habit, presence of supernumerary axillary buds and spines, inflorescence form, corolla form, presence of a deflexed hair-ring and other hair types in the corolla throat, anther orientation, style length, base of stigma (or stylar head complex), and pyrene form including development of an apical-dorsal crest and lateral shoulders. These are characters that have received better documentation or are accessible through the available specimen material, and which could potentially illuminate our comparative studies.

In some cases, we have had to resort to better corroboration of the data. For example, both species of Kanapia were described as "scrambling shrubs", but this is not consistent with documentation on the associated specimen material available in the $\mathrm{BO}$ and $\mathrm{K}$ herbaria. Also, the stipules of Kanapia were noted as being without keels, but in fact there are keels developed; instances such as this have been considered in the decision to exclude stipule characteristics from the present survey, after verification that there were no significant variations for the character.

Nomenclatural considerations follow the International Code of Nomenclature (McNeill et al., 2012). Plant architectural analysis followed the approach of Hallé et al. (1978).

\section{DISTINCTIVE MORPHOLOGY OF TWO ODD 'CANTHIUMS'}

Canthium glabrum was described by Blume (1823) and Canthium confertum by Korthals (1851), and both have remained in that genus unconformably all this time. They are different from a few allied Vanguerieae genera that have been more consistently recognized as genera, such as Perakanthus Robyns ex Ridl. and Psydrax (Wong, 1988; 1989; Puff \& Wong, 2005), and there are apparently no alternative generic or infrageneric names applicable to them.

In Table 1, we present a comparison of these taxa with the allied Bullockia, Cyclophyllum, Kanapia, Keetia, and Pyrostria. It is clear that several characters such as habit, supernumerary buds and spininess are very useful to distinguish between Canthium s.s. (the group containing the type alliance of Canthium Lam.) and the rest of the complex. Some other characters, such as the reflexed anthers and long-exserted styles of Psydrax, or the salverform corollas of Cyclophyllum, seem also distinctive of individual genera. But the genera are, generally, distinguished well only by combinations of characteristics. Importantly, features such as corolla hair types, and pyrene form and their attendant characteristics, appear to group either
Canthium confertum or C. glabrum with certain other taxa, or be useful distinctions.

A feature within Vanguerieae flowers that requires better understanding is the presence and significance of a band of long, stiff deflexed hairs, inserted at or below the corolla throat and found in some taxa but not others (Table 1, Fig. 1B); when such hairs are inserted on a band of thickened tissue, this coincides with a noticeable constriction of the corolla at or below the throat, which often makes the corolla tube or its lower part somewhat bulbous or urceolate. This band of stiff deflexed hairs inserted at or below the throat, and the constriction of the corolla tube below the lobes are characteristics found in a number of genera in the complex, such as Bullockia, Canthium s.s., C. glabrum, Kanapia, Keetia, Perakanthus, and Psydrax, for example, but are significantly lacking in C. confertum (Wong, 1988; 1989) (Fig. 8B), Cyclophyllum (Mouly \& Jeanson, 2015) and Pyrostria (Bridson, 1987). Instead, in Canthium confertum, Cyclophyllum and Pyrostria, only fine, moniliform hairs (which under low magnification have been described as fine, pale crisped hairs: Bridson (1987), Wong (1988; 1989)) congest the upper part of the inner corolla tube and the throat (Fig. 8B, C).

Fine moniliform hairs are also present in addition to the deflexed hair ring at the throat in Canthium glabrum (Koorders 29055及 (BO), Fig. 1) and Kanapia (Elmer 17714 (BO)); however, in Perakanthus only stiff erect unicellular hairs congest the throat in addition to the deflexed hair-ring found (Puff \& Wong, 2005). Perakanthus also has other unique features, such as spiky long erect hairs all over the outer surface of the corolla (compared to glabrous or largely glabrous outer corolla surfaces in Canthium glabrum and Kanapia), and filaments as long as the erect throat hairs and which carry the anthers above the hairs (compared to short filaments that, together with the anthers are in the same level as the throat hairs) (Puff \& Wong, 2005). Canthium glabrum has the throat's moniliform hairs gathered in five distinct dense tufts (each tuft with hairs longest in the middle) in between stamens and opposite to the corolla lobe bases (Fig. 1, 4B), whereas Kanapia has subequally long moniliform hairs distributed densely and evenly as a ring around the throat (Table 1).

Cyclophyllum and Pyrostria are easily distinguished from Canthium confertum by their stigmatic form, which has been described as capitate with a convex base (Mouly \& Jeanson, 2015) or solid with the style attached at the base (Bridson, 1987). The stigma in Canthium confertum has a small basal recess which accommodates the insertion of the style apex (Wong, 1988; 1989) (Fig. 8B) and is therefore more reminiscent of the mitriform stigma or 


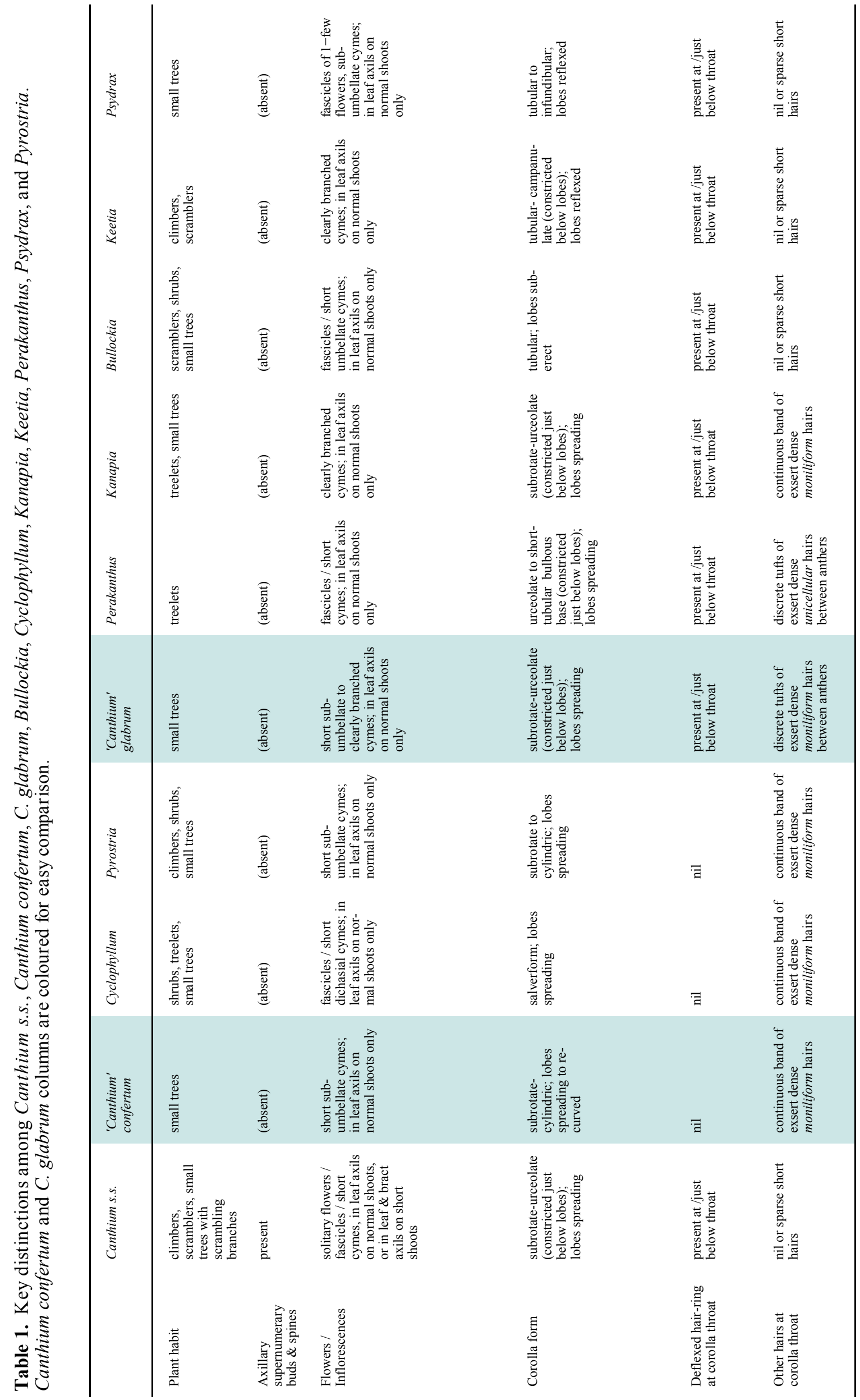




\begin{tabular}{|c|c|c|c|c|c|c|c|}
\hline 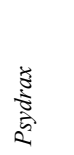 & 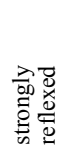 & 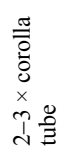 & 吉 & 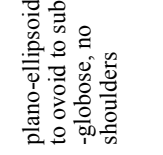 & 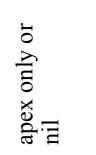 & 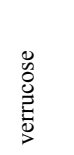 & 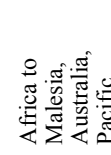 \\
\hline ฐ̃ँ๊ & 遶 & 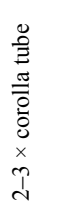 & 总 & 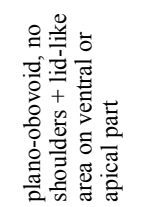 & 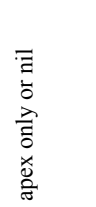 & 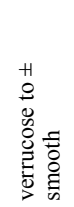 & 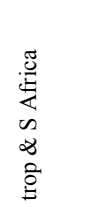 \\
\hline 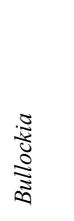 & 总 & 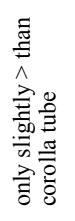 & 莺 & 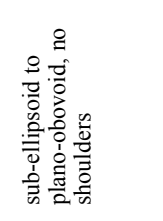 & 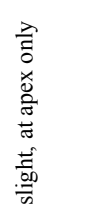 & 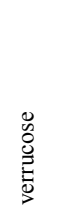 & 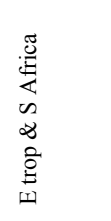 \\
\hline : & 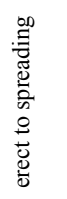 & 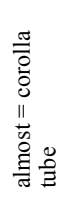 & 言 & 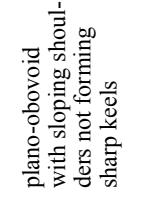 & 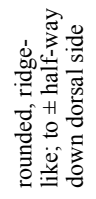 & $\begin{array}{l}0 \\
\stackrel{0}{0} \\
\stackrel{0}{E} \\
\stackrel{5}{D}\end{array}$ & 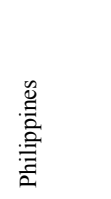 \\
\hline 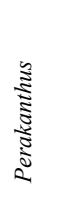 & 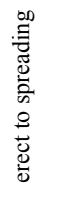 & 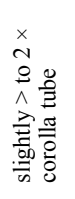 & 言 & 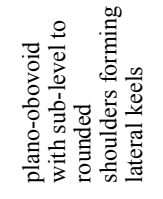 & 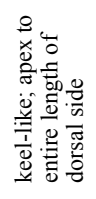 & $\begin{array}{l}\tilde{\overline{0}} \\
\overline{0} \\
\bar{E} \\
\text { H }\end{array}$ & 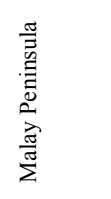 \\
\hline 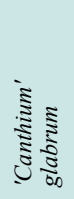 & 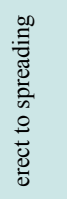 & 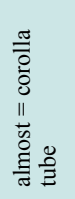 & 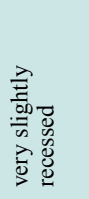 & 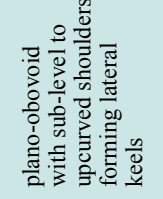 & 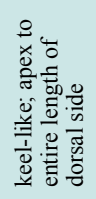 & 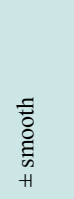 & 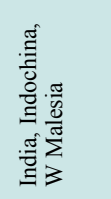 \\
\hline 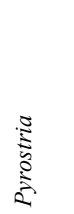 & 忠 & 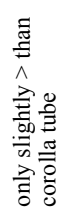 & 疍 & 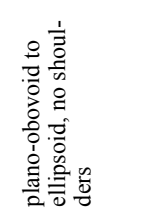 & 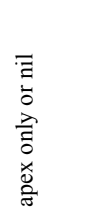 & 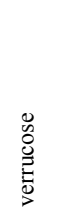 & 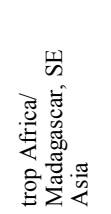 \\
\hline 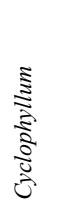 & 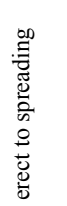 & 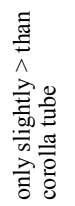 & 总 & 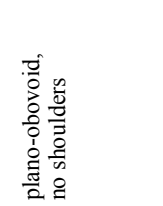 & 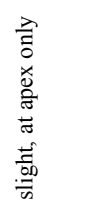 & 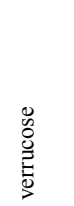 & 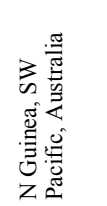 \\
\hline 棓 & 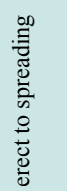 & 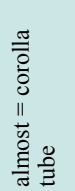 & 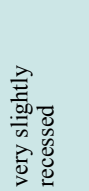 & 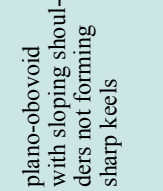 & 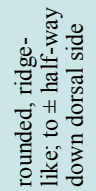 & 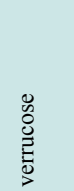 & 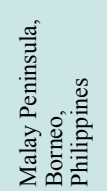 \\
\hline 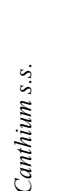 & 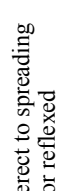 & 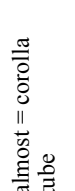 & 䓌 & 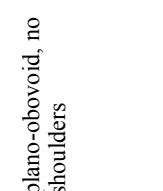 & 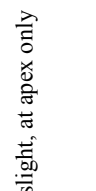 & 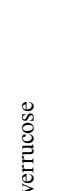 & 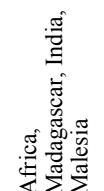 \\
\hline & 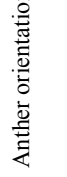 & 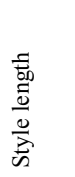 & 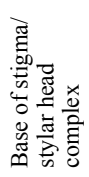 & 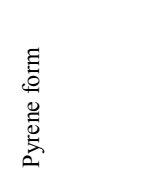 & 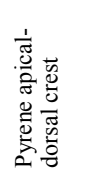 & 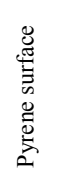 & 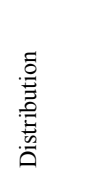 \\
\hline
\end{tabular}




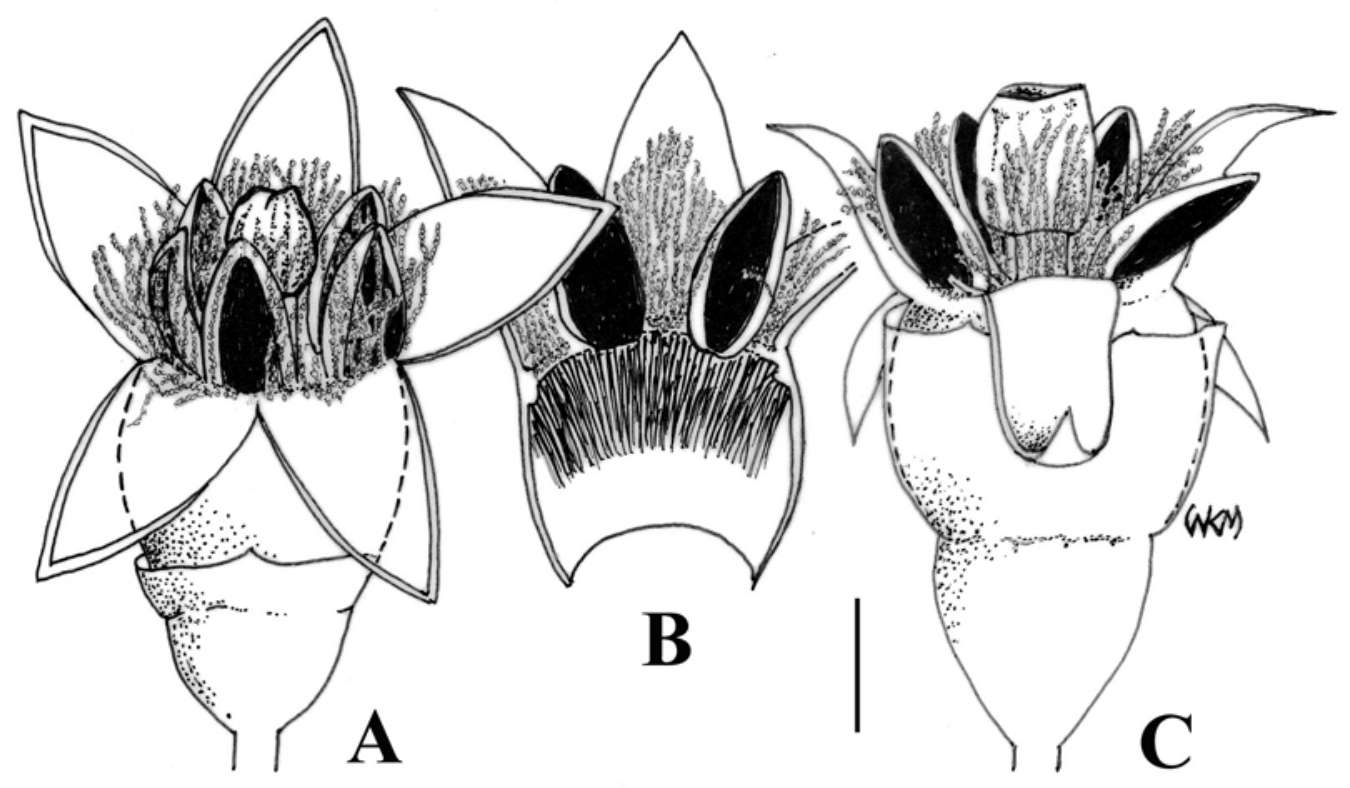

Fig. 1. Flowers of Canthiumera species (formerly placed as 'Canthium glabrum'). A. Canthiumera glabra flower (note short calyx limb). B. C. glabra, longitudinal section through corolla showing ring of stiff deflexed hairs inside the tube and bundles of sub-erect moniliform hairs at the throat. C. Canthiumera robusta flower (note calyx limb as long as, and hiding, corolla tube). [A \& B from Himmah Rustiami HR 2001 (BO); C from M. Nur s.n. 16 A ug 1917 (BO)]. Scale bar is 1 mm. Drawn by K.M. Wong.

stylar head complex (Igersheim, 1993) of a number of genera in the Vanguerieae. Also, Cyclophyllum typically has salverform corollas in which the lobes are much shorter than the tube (Mouly \& Jeanson, 2015); the other two taxa typically have subrotate to cylindric corollas where the lobes are subequal to (i.e., at most only slightly longer or shorter than) the tube (Table 1).

Pyrene form has been found to be distinctive in various genera among the Canthium complex and allies (Bridson, 1985; 1986; 1987), and several taxa from Southeast Asia, including Kanapia, Perakanthus and those identified with Canthium confertum (Figs. 7C, 8E) and C. glabrum (Figs. 2, 4D, 5C \& D6), which have pyrenes that develop a prominent apical-dorsal crest and two lateral 'shoulders', stand out in this regard (Wong, 1988; 1989). All the other Southeast Asian taxa, including Psydrax, have pyrenes that are generally plano-convex and rounded, ovoid, ellipsoid, or obovoid in outline, without distinct keels or shoulders (Table 1).

Whereas the apical-dorsal pyrene crest in Canthium confertum and Kanapia is only slightly developed and at most reaches to about halfway down the pyrene, that in Canthium glabrum and Perakanthus continues as a prominent keel that reaches to the pyrene base (Fig. 2). Accompanying the development of the apical-dorsal crest is a broadening out of the upper lateral parts of the pyrene into 'shoulders'. In Canthium confertum and Kanapia (Fig. 2), the pyrene shoulders are the least prominent among these taxa and slope downwards ca. $45^{\circ}$, whereas in Canthium glabrum and Perakanthus, the shoulders are more level sideways and only slope very slightly or are even slightly upcurved. The pyrene surface in Canthium confertum and Kanapia is verrucose (knobbly or with scattered protuberances) as in many other Vanguerieae genera, but smooth in Canthium glabrum and Perakanthus (Table 1).

Molecular work has indicated some improved taxonomic clarity in this complex (Lantz \& Bremer, 2004; Razafimandimbison et al., 2009) but lack of sampling in Southeast Asian taxa continues to limit resolution of some key areas. While Canthium glabrum has apparently not been included in published molecular phylogenetic analyses, the phylogenetic position of Canthium confertum demonstrated by Razafimandimbison et 


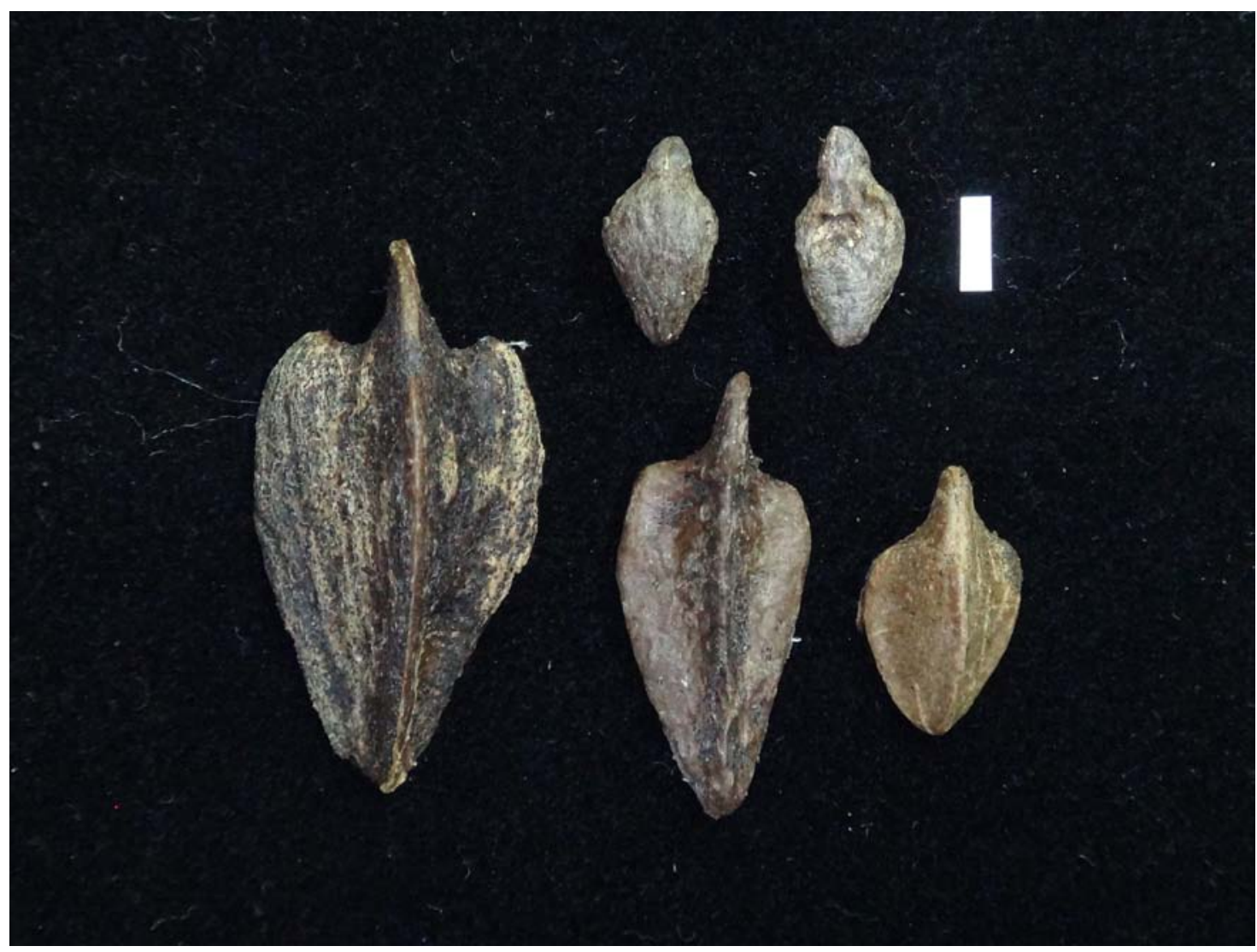

Fig. 2. Pyrenes of Kanapia monstrosa (upper row: dorsal (left) and ventral views) compared with those of species formerly placed as 'Canthium glabrum', presently distinguished as Canthiumera robusta (lower left) and C. glabra (lower centre and right). Scale bar is $5 \mathrm{~mm}$ long. Kanapia from Reynoso et al. PPI 14841, Philippines (BO); C. robusta from Wong WKM 196, Brunei (SING); C. glabra from Ridha s.n., Bogor Botanical Garden (centre) and Nedi \& Idjan 464, W Java (BO). Photo by K.M. Wong.

al. (2009) is of much significance. The latter was recovered in a sister position to the Cyclophyllum clade, and both were in turn well-distinguished from the other Pyrostria s.l. The shared morphological characteristics among Cyclophyllum, Pyrostria and Canthium confertum discussed above (viz. corolla throat congested by moniliform hairs and without a deflexed hair-ring) probably reflect their close phylogenetic relationship parallel to that shown by Razafimandimbison et al. (2009).

Here we describe two new genera in the Vanguerieae, one to accommodate Canthium glabrum and three other species, and another for Canthium confertum and two congeners.

\section{THE NEW GENERA}

Canthiumera K.M.Wong \& Mahyuni, genus novum.

Type species: Canthiumera glabra (Blume) K.M.Wong \& Mahyuni.
Diagnosis. This new genus was previously placed with Canthium Lam. but differs from Canthium s.s. in being arborescent (not scrambling or climbing) in habit and not developing supernumerary axillary buds, axillary spines or axillary short-shoots ('brachyblasts') as in Canthium s.s. It resembles Perakanthus Robyns ex Ridl. in having pyrenes that develop a prominent keel-like apical-dorsal crest that extends down to the pyrene base, with two lateral shoulder-like extensions. However, Canthiumera has a glabrous or largely glabrous outer corolla surface, flexuoussuberect moniliform hairs above a ring of deflexed hairs at the corolla throat, and short filaments that, together with the anthers, are at the same level as the throat hairs, whereas Perakanthus has spiky erect long hairs all over the corolla outer surface, stiff erect unicellular hairs above the ring of deflexed hairs at the corolla throat, and its filaments are as long as the throat hairs and carry the anthers above the hairs.

Trees. Stipules triangular-ovate, with a slight to pronounced median keel prolonged into an apical 


\section{Key to Canthiumera species}

1. Corolla tube in open flower mostly to entirely hidden by the calyx limb. Pyrenes with sub-horizontal to slightly uparched shoulders 3. C. robusta

Corolla tube in open flower conspicuous with only the base hidden by the calyx limb. Pyrenes with shoulders sloping downward

2. Corolla broadly cylindric and slightly flared outwards. Leaf margin and veins on lower surface with long spreading hairs 2. C. neilgherrensis

Corolla urceolate and inflated. Leaf margin glabrous, veins on lower surface glabrous to subpuberulent

3. Calyx 1-1.5 mm long; corolla lobes about the same length as the tube; style puberulent ... 1. C. glabra Calyx 2-2.5 mm long; corolla lobes longer than the tube; style glabrous 4. C. siamensis

cusp or lobe. Leaves opposite and decussate on vertical stem axes but distichous on lateral (horizontal) branches; frequently with pit-domatia in the axils of secondary or higher-order veins. Inflorescences axillary on lateral branches, pedunculate, cyme-like or sub-umbellate, bracts small and inconspicuous. Flowers bisexual; corolla subrotate-urceolate to broadly cylindric, constricted just below corolla lobes, glabrous or short-pubescent outside, throat with dense tufts of erect-spreading (becoming flexuous-crisped) moniliform hairs longest at the base of corolla lobes, the tube around the same length as the lobes or shorter, inside with a ring of stiff deflexed hairs just below the throat, corolla lobes spreading in the open flower; stamens alternate with the corolla lobes and not longer than the corolla throat hairs, anthers ovate with broad connective, suberect to spreading, inserted on short filaments at the throat; style glabrous or pubescent, stigma globose to club-shaped, with a slight basal recess; ovary with 2 locules, each locule with a solitary ovule inserted near the upper part. Fruits ellipsoid, obovoid or obcordate-compressed; pyrenes obovoid-compressed, ventrally plane, dorsally with a prominent keel-like crest reaching to the base, laterally with two sub-apical extensions ('shoulders') flattening out as keels and reaching to the base, smooth. Seeds one in each pyrene.

Distribution. India, Myanmar, Thailand, Indochina, West Malesia (Sumatra, Malay Peninsula, Java, Borneo); four species.

Etymology. The genus name is composed of Canthium, the genus with which it was confused, and the Latin umerus which means shoulder, referring to the prominent lateral extensions in the pyrene.

1. Canthiumera glabra (Blume) K.M.Wong \& Mahyuni, comb. nov. (Fig. 1A, B; 2)

Basionym: Canthium glabrum Blume, Cat. Gew.
Buitenzorg (Blume) (1823) 45; Bijdr. Fl. Nederl. Ind. 16 (1827) 967; Candolle, Prodr. 4 (1830) 474; Backer \& Bakhuizen, Fl. Java 2 (1965) 320. Plectronia glabra (Blume) Koorders \& Valeton in Koorders, Exkursionsfl. Java 3 (1912) 260 (in clavi), Bijdr. Booms. Java 8 (1912) 137. Psydrax glabra (Blume) Deb \& M.Gangop., Nelumbo 54 (2012) 267. - Type: C.L. Blume s.n., Java, Salak, "ki-tja rolok" (holotype L [L0062935]).

Other specimens examined. Bali. Jembrana, Dewasana, 23 Apr 2014, Himmah Rustiami HR 2001 (BO); Ubud, Monkey Forest, 5 Apr 1975, $W$. Meijer \& Noerta 8087 (BO). Java. No specific locality, no date, C. L. Blume s.n., Java "var. puberula" (L [L0057512, L0057513, L0057514]), C.L. Blume s.n., Java (L [L0058032, L0058033, L0062934], P [P03937196, P03937201]), $H$. Forbes 373 (BO), 22 Mar 1899, S.H. Koorders Kds $33131 \beta$ (BO). Central Java. Banjarnegara, 19 Nov 1891, S.H. Koorders Kds 6484 $\beta$ (BO); Banjumas, no date, S.H. Koorders $20095 \beta$ (P [P03937200]), 13 Apr 1923, P. Tunner 6246 (BO); Banyuwangi ('Besoeki, Rogodjampi'), 7 Sep 1897, S.H. Koorders Kds 29055 $\beta$ (BO), 1900, S.H. Koorders Kds 29058ß (BO); Jepara, 20 Apr 1936, Wagiman 30 (BO); north of Kudus, Gunung Muria, Tjollo, 25 Nov 1951, A. Kostermans 6271 (BO); Nusakambangan, 16 Sep 1896, S.H. Koorders Kds $24602 \beta$ (BO); Pekalongan, $12 \mathrm{Apr}$ 1928, Hoffmann 6240 (BO), 11 Apr 1897, S.H. Koorders Kds $27526 \beta$ (BO); Prov. Semarang, no date, S.H. Koorders 6485 (P [P03937199]); Semarang, Telawa, 21 Aug 1923, Vincent 4696 (BO), Semarang, Ambarawa, Telomojo, S.H. Koorders Kds $27914 \beta$ (BO); Prov. Tegal, S.H. Koorders 6522 $\beta$ (P [P03937198]). East Java. Jember, 1930, C.A. Backer 17746 (BO); Kediri, Soekaradja, 1896, S.H. Koorders Kds $22646 \beta$ (BO), 30 May 1896, S.H. Koorders Kds $22789 \beta$ (BO); Malang, Jul 1930, Ag. Ulteê 1 (BO), 13 May 1896, S.H. Koorders Kds 23514及 (BO); Pasuruan, Gunung Arjuno, 1900, S.H. Koorders Kds $23957 \beta$ 
(BO); 1913, S.H. Koorders Kds $38216 \beta$ (BO); Ponorogo, Madiun, 1901, S.H. Koorders Kds $38781 \beta$ (BO). West Java. Banten, Cikandi, 1 May 1933, Sheildi s.n. (BO); Bogor Botanic Garden, IVE.146, 28 Jan 1927, Anonymous s.n. (BO); Bogor, Laladon, Ciomas, 19 Apr 1920, R.C. Bakhuizen v.d. Brink 3437 (BO), 23 Jan 1921, R.C. Bakhuizen v.d. Brink 5106 (BO); Cibodas, Ciampea, 13 Jan 1929, C.G.G.J. van Steenis 2695 (BO); Ciburial, 22 Feb 1951, Nedi \& Idjan 464 (BO); Depok, no date, 1901, Sugandiradja 237 (BO); Garut, 19 Aug 1893, S.H. Koorders Kds 13972 $\beta$ (BO); Jampang Kulon, 28 Aug 1891, S.H. Koorders Kds 6497 $\beta$ (BO); Lewiliang, 9 Dec 1928, van LeeuwenReijnvaan 11985 (BO); Kalapanunggal, 24 Dec 1920, V. G.e 590 (BO), 24 Dec 1920, C.A. Backer 31112 (BO); Pelabuhan Ratu, 1900, S.H. Koorders $K d s$ 12296 $\beta$ (BO); Sukabumi, Preanger, Pangentjongan, Aug 1899, S.H. Koorders Kds $11803 \beta$ (BO), Apr 1898, S.H. Koorders Kds $26702 \beta$ (BO), 5 Apr 1899, S.H. Koorders Kds $34302 \beta$ (BO); Tasik Malaya, 25 Jul 1917, S.H. Koorders Kds $47943 \beta$ (BO); 5 Aug 1917, S.H. Koorders Kds $47928 \beta$ (BO); Tegal Sapi, 5 Jan 1924, 240 m, R.C. Bakhuizen v.d. Brink 3180 (BO). Sumbawa. West Sumbawa, Sumbawa Besar, Semongkat Atas, Kuswata $122(\mathrm{BO})$.

\section{Canthiumera neilgherrensis (Wight)}

K.M.Wong, comb. nov. (Fig. 3)

Basionym: Canthium neilgherrense Wight, Icon. P1. Ind. Orient. 3(4) (1846) 4, tab. 1064bis. Canthium neilgherrense var. 1, Hooker f., Fl. Brit. India 3 (1880) 133. Plectronia neilgherrensis (Wight) Bedd., Fl. Sylv. S. India Forester's Man. Bot. (1872) cxxxiv/6. - Type: Wight s.n., India, Sisparah on the Neilgherries, no date ("presented 1871") (holotype K [K000763659]).

Canthiumera neilgherrensis var. chartacea (Gamble) K.M.Wong, comb. nov.

Basionym: Plectronia neilgherrensis var. chartacea Gamble, F1. Madras (1921) 441. Canthium neilgherrense var. chartacea (Gamble) Swamin., Biol. Mem. 2(1-2) (1977) 67. Canthium neilgherrense var. 2, Hooker f., F1. Brit. India 3 (1880) 133. - Type: Wight s.n., India, Pulney Mountains, Sep 1836 (lectotype K [K000031505], here designated).

Other specimens examined. India. Pulneys, no date Wight 1422 (K [K000031506, K000031507]).

Note. Miquel (1857) was the first to point out that Canthium glabrum was not distantly related from ("Haud longe distare videtur") C. neilgheirense (sic!) Wight.

Canthiumera neilgherrensis var. chartacea has chartaceous leaves with 5-6 pairs of secondary veins, compared with the typical variety which has coriaceous leaves with 6-8 pairs of secondary veins. There is too scant material on which to consider if these differences are truly consistent; furthermore, flowers are known only for the typical variety.

3. Canthiumera robusta K.M.Wong \& X.Y.Ng, spec. nov. - Type: X.Y. Ng et al. SING 2018409, Singapore, Mandai Road Track 7, 11 Jun 2018 (holotype SING; isotypes K, BO, A, KEP, L, BRUN, SGN, SAN, BKF).

Diagnosis. The new species Canthiumera robusta is superficially similar to Canthiumera glabra (Blume) K.M.Wong \& Mahyuni, but differs in having mature flowers with the corolla tube mostly to completely hidden by the calyx limb and pyrenes with slightly uparched lateral extensions. In contrast, Canthiumera glabra has mature flowers with only the corolla tube base hidden by the calyx limb and pyrenes with rounded to downwardly sloping lateral extensions. (Fig. 1C, 2, 4, 9, 10)

Canthium glabrum auct. non Blume (1823): Korthals, Nederl. Kruidk. Arch. 2(2) (1851) 234, p.p.; Miquel, Fl. Nederl. Ind. 2 (1857) 254, p.p.; Hooker f., Fl. Brit. India 3 (1880) 133, p.p.; King \& Gamble, J. Asiat. Soc. Bengal, Pt. 2, Nat. Hist. 73(3) (1904) 61, p.p.; Ridley, F1. Malay Penins. 2 (1923) 124, p.p.; Craib, F1. Siam. Enum. 2(1) (1932) 139, p.p.

Tree to $25 \mathrm{~m}$ tall. Stipules with a basal triangular-ovate portion 2-3 $\mathrm{mm}$ long and a pronounced median keel prolonged into an apical cusp or lobe to $5 \mathrm{~mm}$ long. Leaves ovate to elliptic, 7-18 × 3-9 cm, apex acute to slightly cuspidate, base obtuse-rounded to cuneate, typically subcoriaceous when fresh but often drying with a chartaceous texture, secondary veins (5-)6-8(-10) pairs, frequently with pit-domatia in the axils of secondary or higher-order veins, often with intermediate veins in between secondaries; petioles 7-14 $\mathrm{mm}$ long. Inflorescences with short peduncles 1-3 $\mathrm{mm}$ long and branches $3-6 \mathrm{~mm}$ long, the axes mostly glabrescent, rarely scantily hispid. Flowers on short pedicels 2-3 mm long; calyx obconical, hypanthium 1.5-2 mm long, limb $c a$. $1.5-2 \mathrm{~mm}$ long with 5 minute triangular teeth; corolla subrotate-urceolate, constricted just below corolla lobes, glabrous, tube $c a$. $1.5-2 \mathrm{~mm}$ long and nearly to completely hidden by the calyx limb in the open flower, throat with dense tufts of pale erect-spreading (becoming flexuous-crisped) moniliform hairs longest at the base of corolla lobes, inside with a ring of stiff deflexed hairs just below the throat; corolla lobes around the same length as the tube or slightly longer, spreading to slightly recurved in the open flower; stamens with 


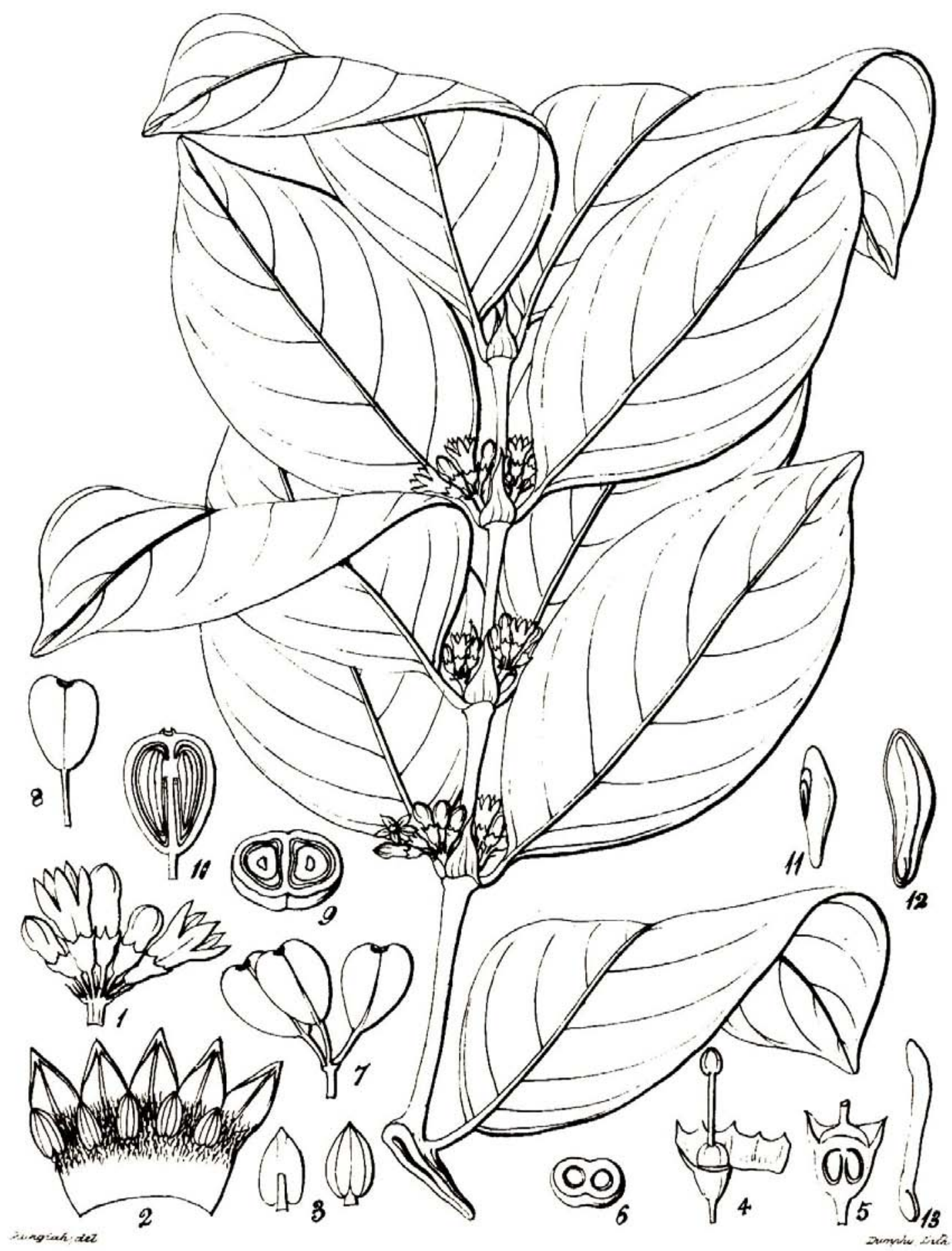

Fig. 3. Canthiumera neilgherrensis, reproduced from Wight, Icon. Pl. Ind. Orient. 3(4) (1846) tab. 1064bis. The main drawing depicts a flowering leafy branch. The numbered parts are: 1 . Inflorescence; 2 . Inside of split corolla; 3. Dorsal (L) and ventral views of anther; 4. Flower with corolla and part of calyx removed, showing disk and gynoecium; 5. Longitudinal section through ovary, disk and calyx; 6 . Transverse section through ovary; 7. Cluster of fruits; 8 . Single fruit; 9. Transverse section through fruit; 10 . Longitudinal section through fruit showing attachment of pyrenes in the locules; 11. Lateral view of young pyrene; 12. Longitudinal section through seed showing embryo within; 13. Embryo with cotyledonary primordia at bottom. Scales omitted for simplicity. 
anthers $2-2.5 \mathrm{~mm}$ long on short filaments $c a .0 .5$ $\mathrm{mm}$ long, suberect to spreading in the open flower; style 2.5-3 mm long, glabrous, stigma 1-1.5 mm long, globose to club-shaped, with a slight basal recess; ovary with 2 locules, each locule with a solitary ovule. Fruits ellipsoid to obovoid, 4-ridged when dry, to $50 \times 36 \mathrm{~mm}$ when fresh, $40 \times 28 \mathrm{~mm}$ when dried, ripening dark bluish green to purplish black, drying black; pyrenes to $44 \times 26 \mathrm{~mm}$, ventrally plane, the dorsal crest keel-like, to 5-7 mm wide, continuous and narrowing from apex to base, the shoulders sub-horizontal to slightly upcurved, extending as keels 2-4 mm wide down to the base, smooth. Seeds one in each pyrene.

Notes. Both Korthals (1851) and Miquel (1857) adopted the name Canthium glabrum for Bornean and Sumatran material, respectively. Hooker (1880) listed Canthium glabrum Blume as being distributed "from Tenasserim, Pegu, and the Andaman Islands, to Singapore and Penang", besides Java. Thus began a misassumption that was perpetuated in the absence of revisionary studies across the region, an effort long delayed by the morphologically very mixed nature, and formidable species richness, of the entire Canthium complex. In the ensuing floristic treatments for the Malay Peninsula by King \& Gamble (1904), Ridley (1923), Craib (1932), and Wong $(1988 ; 1989)$, and for Borneo by Coode et al. (1996), the identity Canthium glabrum was used; Merrill (1921) adopted Plectronia glabra.

Canthiumera robusta has pyrenes that reach $40 \times 24 \mathrm{~mm}$ in wild, presumably crossed, material, but batches of smaller pyrenes up to only $26 \times 16 \mathrm{~mm}$ have also been found in the wild, as well as in nursery generated material (through uniparental or biparental selfing) raised from the same mother tree. The degree of sensitivity to inbreeding depression has not been investigated.

Other specimens examined. (All glabrous inflorescences.) Anambas Island. (Indonesia.) Pulau Siantan, 30 Mar 1928, C.G.G.J. van Steenis 749 (BO), east coast, 30 Mar 1928, M.R. Henderson SFN 20144 (BO, SING [SING0190655]). Borneo. Brunei Darussalam. Belait district: Labi, Kampong Tenajor area, 27 Nov 1988, Mohd Haslani Abdullah HA 47 (BRUN, SING [SING0189228]). Brunei Muara district: Jerudong, Bukit Shahbandar, 10 Mar 1988, K.M. Wong WKM 196 (SING [SING0189307]). Tutong district: Layong-Gadong pipeline track, 1 Mar 1992, J. Dransfield et al. JD 7234 (BRUN, KEP). Indonesia. West Kalimantan: Sungei Landak, no date, Teysmann 19297 (BO). Malaysia. Sabah: Kinabatangan, Bukit Garam, 25 Feb 1987, George et al. SAN 117635 (SAN); Ranau, Kampung Kituntul, 21 Jan 1986, Amin et al. SAN 106843
(SAN), Solong, 20 Jun 1987, Amin et al. SAN 118136 (SAN). Sarawak: Bukit Rawan Tebakang Area, 1 Apr 1983, D. Awa \& I. Paie S. 45248 (SAN); Kapit, Bena Sut, Sungei Marting, 9 Nov 1988, Othman et al. S. 62157 (K, KEP [KEP137583], L, MO, SAN, SAR). Malay Peninsula. Malaysia. Johor: Mawai, 17 Jan 1938, Ngadiman SFN 34763 (BO); Ulu Sebol FR, 7 Feb 1980, P. Vethevelu FRI 25321 (KEP [KEP208482]); Sungei Sebong, Jason Bay, 15 Jun 1934, E.J.H. Corner SFN 28532 (SING [SING0189319]). Kedah: Gunong Jerai, 3 Mar 1957, K.M. Kochummen KEP 85076 (KEP [KEP208426]); Langkawi Island, Bt. Sawar FR, 11 Dec 1969, T.C. Whitmore FRI 15001 (SING [SING0189503]). Kelantan: Stong, Tengah FR, Sungei Semuliang, $5^{\circ} 18.92^{\prime} \mathrm{N}, 1^{\circ} 1^{\circ} 56.77^{\prime} \mathrm{E}, 500$ m, M.Y. Chew \& A. Angan FRI 53479 (SING [SING0110032]); Ulu Kelantan, Gunung Rabong, 2000 ft, 11 Mar 1972, T.C. Whitmore FRI 20606 (KEP, SING [SING0189342]), 2500-3300 ft, 12 Mar 1972, Mohd. Shah. MS 2512 (KEP [KEP181919], SING [SING0189441]). Melaka: 2 Aug 1885, V.M. Alvins 2060 (SING [SING0189317]); Bt. Bruang, Jul 1890, R. Derry 398 (SING [SING01893210]). Pahang: Bentong, Sabai Estate, 27 Jan 1958, Mohd. Sah, 173 (BO, SING [SING0189311]); Cheraga, Sg. Telom, 1000 ft, 26 May 1971, Zainudin b. Sohadi FRI 14734 (KEP [KEP181909]), $1200 \mathrm{ft}, 26$ May 1971, T.C. Whitmore FRI 20030 (SING [SING0189334]); Jerantut, 8 Mar 1996, L.E. Theo \& Olivier Tarelli KL 4568 (KEP); Kuala Lompat, Lata Tujuh, 2500 ft, 24 Apr 1978, Y.C. Chan FRI 25125 (KEP [KEP181911], SIN [SING0189344]); Kuantan, 2 Mar 1931, M. Soh 15117 (SING [SING0189310]). Penang: Sep 1886, C. Curtis 988 (SING [SING0189313]); Balik Pulau, Jun 1898, H.N. Ridley 9421 (SING [SING0189443]); Penara Bukit, Apr 1901, C. Curtis s.n. (SING [SING0189246]). Perak: Bubu FR, 5 Apr 1933, D.B. Arnot, 30665 (KEP [KEP181912]); Kledang Saiong, 4 Mar 1931, Symington KEP 25637 (KEP [KEP181918]); Kledang Saiong FR, 3 Apr 1934, D.B. Arnot KEP 33690 (KEP [KEP181915]); Sungei Guar valley, T.C. Whitmore, FRI 0675 (SING [SING0189459]); Ulu Bubong, 1886, King's Coll. 10199 (SING [SING0189320]); Ulu Sepetang, 25 Feb 1909, M. Ashin 235 (KEP [KEP208471]). Selangor: 24 Sep 1916, G.E.S. Cubitt 847 (SING [SING0189314]); Kuala Lumpur, Weld Hill Reserve, 24 Sep 1916, F.G. Hamid 847 (KEP [KEP208453]); Kuala Kubu, 8 Apr 1980, K.M. Kochummen KEP 29084 (SING [SING0189389]); Kepong, Bt. Lagong FR, 10 Jan 1967, Gerus KEP 99458 (SING [SING0189502]); Templer Park, 11 Feb 1971, T.C. Whitmore FRI 15844 (KEP [KEP208488], SING [SING0189337]). Terengganu: Bukit Kajang, 500 ft, 17 Nov 1935, E.J.H. Corner SFN 30504 (SING 

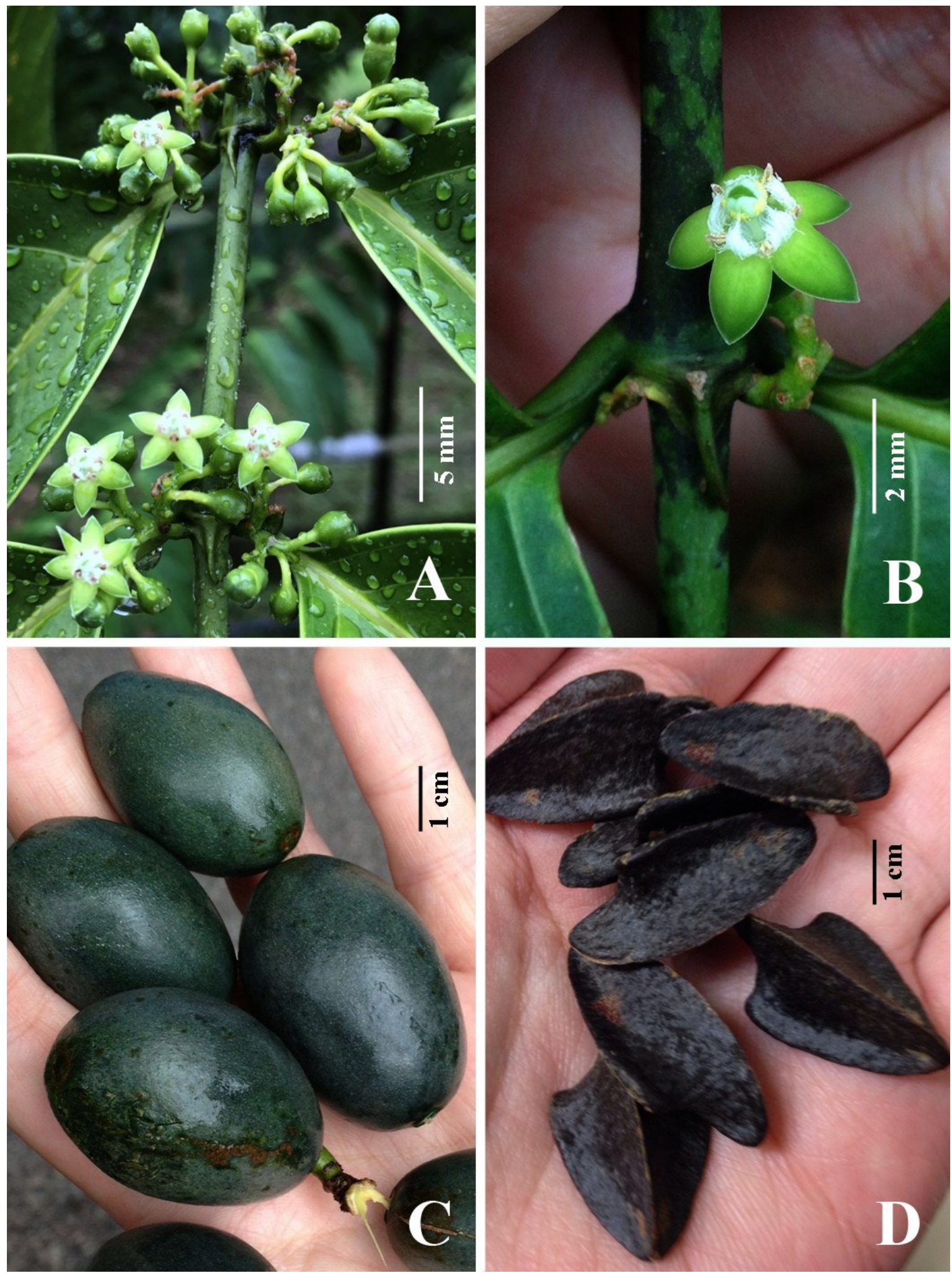

Fig. 4. Canthiumera robusta K.M.Wong \& X.Y.Ng, spec. nov. A. Leafy branch with inflorescences; note also keeled stipules. B. Flower with tufts of pale moniliform hairs visible opposite corolla lobes. C. Fruits. D. Pyrenes. Photos by Ang Wee Foong (A) and X.Y. Ng (B-D). 
[SING0189312]); Dungun, Bt. Bauk FR, 15 May 1976, Y.C. Chan FRI 25068 (KEP, SING [SING0189393]); Kemaman, 500 ft, 10 Nov 1935, E.J.H. Corner SFN 30362 (BO), Kemaman, Ulu Bendong, 1 Nov 1936, E.J.H. Corner SFN 30119 (BKF [SN125134], SING [SING0189316]); Gunung Padang, 400 ft, 16 Sep 1969, T.C. Whitmore FRI 12621 (SING [SING0189315]). Singapore. Botanic Gardens, Lower Garden, 16 Aug 1917, Md. Nur s.n. (BO), 17 Sep 1931, Md. Nur s.n. (BO); near Bukit Kallang, 16 Sep 1982, J.F. Maxwell 82-255 (BKF [SN124973]); Bukit Mandai, 9 Apr 1892, H.N. Ridley 4434 (SING [SING0019983]); Mandai Road Track 7, 11 Jun 2018, X.Y. Ng et al. SING 2018-631 (SING, K); Bukit Timah NR, 15 Apr 1970, R.D. Hill H.314 (SING); MacRitchie Reservoir, 10 Mar 1977, Samsuri Ahmad SA 1456 (SING [SING0019988]); Nee Soon Swamp Forest, 12 Jun 2007, D. Liew 2007-331 (SING [SING0093484]); Seletar, no date, 1891, H.N. Ridley 6718 (SING [SING0019989]); Sungei Hantu opposite Pulau Serimbun, 28 Mar 1953, J. Sinclair SFN 39530 (SING [SING0239956]); Tuas, no date, 1892, J.S. Goodenough 3984 (SING [SING0019984]). Peninsular Thailand. Ka soom, Nov 1896, C. Curtis 3249 (SING [SING0189545, SING0192941]). Khaw Pak Hill, 1 Dec 1918, M. Haniff \& M. Nur 3647 (BO, SING [SING0192939]). Yala, way to Be Tong, 150 m, 19 Dec 1972, T. Santisuk \& B. Nimanony 444 (BKF [SN105492]). Sumatra. (Indonesia.) Simaloer, 12 Nov 1917, Achmad 77 (BO), 15 Jan 1918, Achmad 184 (BO), 25 Nov 1918, Achmad 759; Gayo Alaslanden Lami Sagoe, 21 Jun 1904, Pringgar Atmodjo 447 (BO). Riau: Pulau Karimun, 26 May 1890, H.N. Ridley 1620 (SING); Tiga Puluh Mountains, Bukit Karampal area, $0^{\circ} 46^{\prime} \mathrm{S}, 102^{\circ} 32^{\prime} \mathrm{E}$, ca. $100 \mathrm{~m}, 13$ Nov 1988 , J.S. Burley, Tukirin et al. 1435 (BO, SING [SING0192610]); Batoe Paulajeh, 600 ft, H.O. Forbes 2678 (BO); Sibual-bual, Sipirok, 27 May 1993, J.J. Afriastini 2516 A (BO).

Canthiumera robusta material with slightly hispid inflorescence branches include the following: Malay Peninsula. Malaysia. Kedah: Langkawi Island, Bt. Sawar FR, 11 Dec 1969, T.C. Whitmore s.n. (KEP [KEP208464]). Perak: no date, L. Wray Jr. 1369 (SING [SING0189388]). Thailand. Tongkah, Aug 1892, Hamid s.n. (SING [SING0189546, SING0192940]). Bomeo. Malaysia. North Borneo, Dec 1912, Amdjah 981 (BO).

4. Canthiumera siamensis (K.Schum.) K.M.Wong, comb. nov. (Fig. 5, 6)

Basionym: Plectronia siamensis K.Schum., Bot. Tidsskr. 24 (1902) 335. Canthium siamense (K.Schum.) Pitard, Flore générale de l'Indochine 3 (1924) 300. - Type: J. Schmidt 622, Siam, Chantaburi, Koh Chang, near Lem Dan, 25 Feb 1900 (holotype C [C10018081], isotype $\mathrm{K}$ [K000763638]).

Canthium glabrum var. pedunculatum Pitard, Flore générale de l'Indochine 3 (1924) 292. Type: M. Poilane 1969, Laos, Sam nuea, 29 Sep 1920 (lectotype P [P03937320], here designated; isolectotype P [P03937322]).

Canthium glabrum auct. non Blume (1823): Pitard, Flore générale de l'Indochine 3 (1924) 291, p.p.; Craib, Fl. Siam. Enum. 2(1) (1932) 139, p.p.

Plectronia glabra auct. non (Blume) Koorders \& Valeton (1912): Kurz, J. Asiat. Soc. Bengal, Pt. 2, Nat. Hist. 46(2) (1877) 153, Forest Fl. Burma 2 (1877) 35, p.p.

Other specimens examined. Andamans. No specific locality, no date, King's Coll. 201 (P [P03937352]), 8 Mar 1901, Prain's Coll. 16 (P [P03937304]); S Andaman, N Corbyn's Cove, 27 Jan 1894, King's Coll. s.n. (P [P03937351]). Cambodia. Koh Kong province, Phnom Phlong Saom, $300 \mathrm{~m}$ asl, 4 Mar 1966, M. Martin 296 (P [P03937323]), Timor Sor Village, $98 \mathrm{~m}$ asl, 18 Nov 2009, S.K. Cheng et al. CL 1210 (SING [SING0174972]); Siem Reap \& Angkor, 21-22 Dec 1917, A. Chevalier 36232 (P [P03937164]).

India. Assam. Sibsagar, Peal 169 (P [P03937305]). Laos. Prov. Bassac, entry to B. Phinh \& B. Niong keo, $200 \mathrm{~m}$ asl, 18 Oct 1928, $M$. Poilane 16016 (VNM [VNM00011999]); Sanavakhet to Quangtri, km 130, 9 Jan 1925, M. Poilane 11553 (VNM [VNM00011998]). Myanmar. Coast of Tenasserim, no date, W. Gomez in N. Wallich 8412 (K [K000031514]), N. Wallich 8412B (K [K000031515]). Thailand. No locality, no date, A.F.G. Kerr 7938 (TCD [TCD0017737]), Kerr 17608 (TCD [TCD0017738]). E Thailand. Chaiyaphum province: Khon Shan district, Kamang, Trung, Phu Khiao Wildlife Sanctuary, 22 Jan 2004, T. Wongprasert \& S. Khaoiam 41-14 (BKF [SN144326, SN144327]). Nakhon Ratchasima province: Bahk Chong district, Khao Yai National Park, Wang Jumpee area, $14^{\circ} 27^{\prime} \mathrm{N}, 101^{\circ} 23^{\prime} \mathrm{E}, 725$ $\mathrm{m}, 17$ Aug 2002, S. Somchin 4 (BKF [SN155704]), Khao Yai National Park, Haew Suwat waterfall, $14^{\circ} 45^{\prime} \mathrm{N}, 102^{\circ} \mathrm{E}, 800 \mathrm{~m}, 20$ Oct 1969, C.F. van Beusekom \& C. Charoenpol 1975 (BKF [SN050566], L). $\boldsymbol{N}$ Thailand. Chiang Mai province: Muang district, Doi Sutep-Pui National Park, Chang Kian Valley, 975 m, 24 Feb 1995, J.F. Maxwell 95-159 (BKF [SN091345], CMU). Lampang province: Muang Bahn district, Jae Sown National Park, Bah Miang village, 1 Dec 1995, J.F. Maxwell 95-1217 (BKF [SN108748], CMU). Nan province: Pua district, Doi Phu Ka National Park, 900 m, 24 Nov 1999, T. Wongprasert s.n. (BKF [SN112175, SN112176]). NE Thailand. Nong Khai province: Buong Karn district, Wat Chotinos Mammakorn, ca. 100 m, 25 Jan 


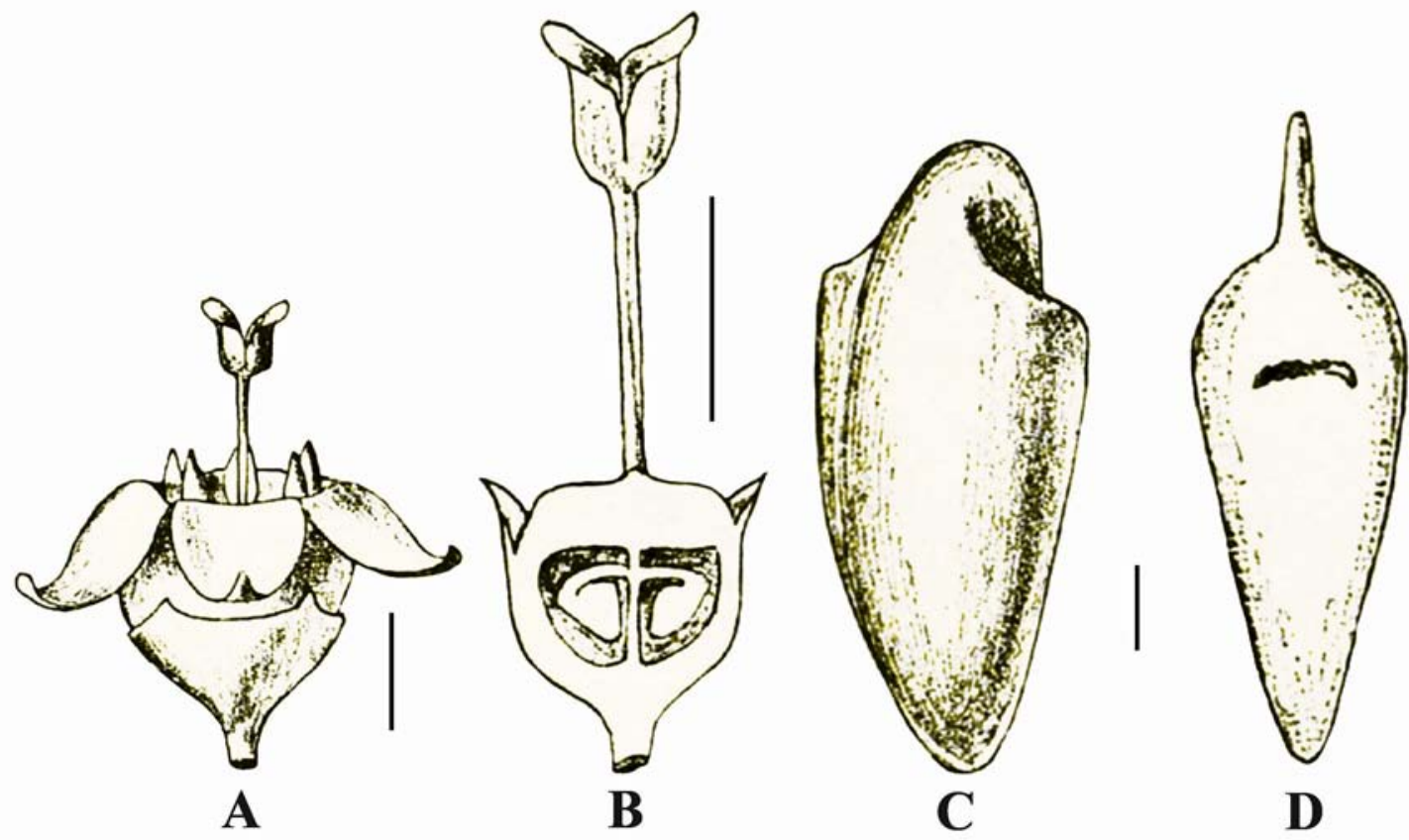

Fig. 5. Canthiumera siamensis. A. Flower. B. Longitudinal section through flower with corolla removed, showing ovule attachment in ovary locules and style with 2-lobed stigma. C. Pyrene, oblique-dorsal view. D. Pyrene, ventral view showing transverse scar of placental attachment. Scale bars are $2 \mathrm{~mm}$. Reproduced from J. Pitard (1924) in F. Gagnepain, H. Lecomte \& H. Humbert (eds), La Flore générale de l'Indochine Vol. 3.

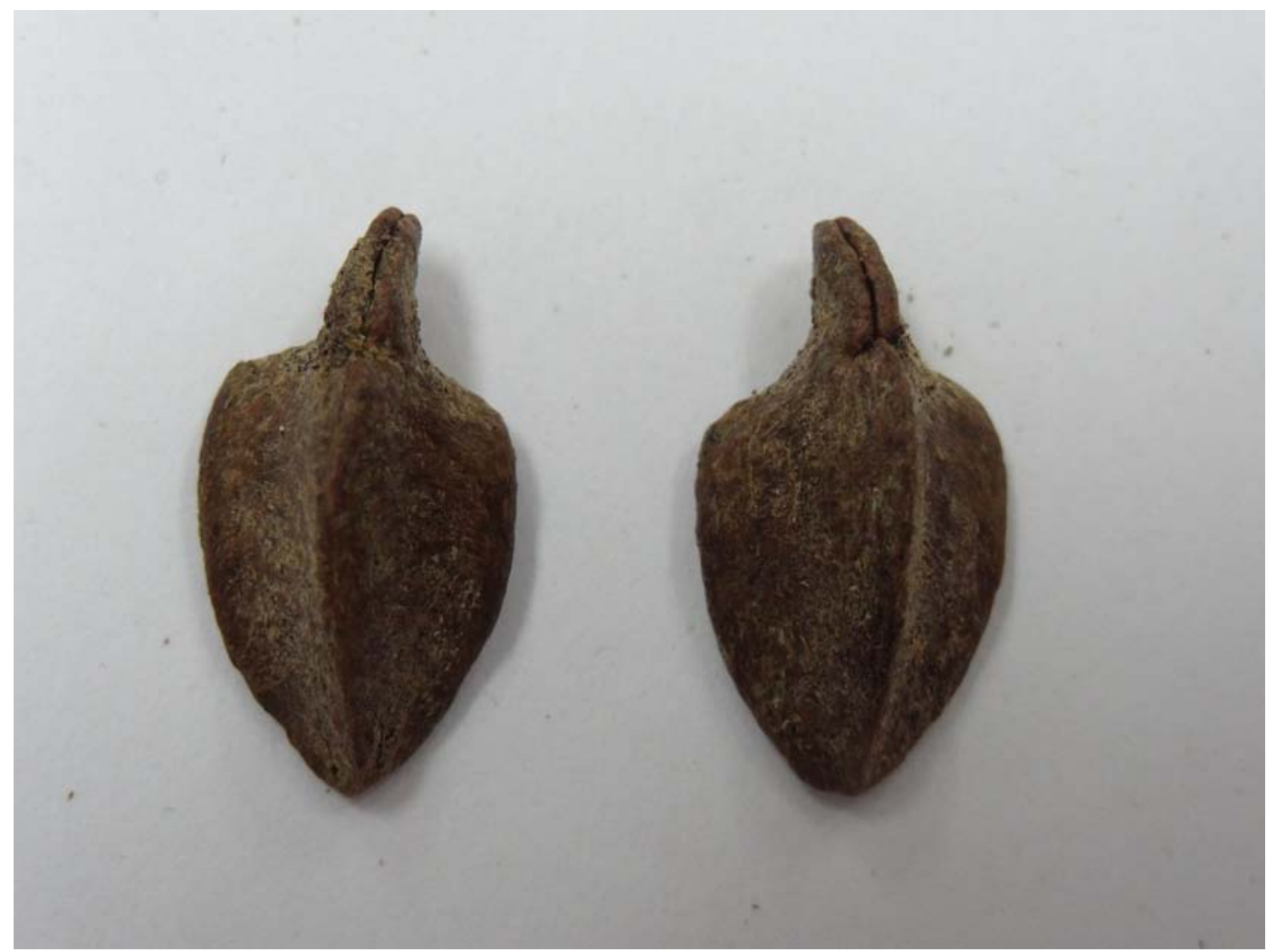

Fig. 6. Canthiumera siamensis: pyrenes in dorsal view, with the vertical preformed germination slit along the dorsal crest visible. The pyrenes are $17 \mathrm{~mm}$ long. From Thorel 1234, 'Cochinchine' (BO). 
2004, T. Wongprasert \& S. Khaoiam 41-58 (BKF [SN144267, SN144268]). Peninsular Thailand. Nakhon Si Thammarat province: Tung Song district, Yong waterfall, 17 Mar 1972, T. Santisuk \& B. Nimanony 285 (BKF [SN120409, SN120410]). Narathiwat province: Sungei Kolok district, Nikom Waenge, $5^{\circ} 50^{\prime} \mathrm{N}, 101^{\circ} 50^{\prime} \mathrm{E}, 200 \mathrm{~m}, 28$ Feb 1974 , K. Larsen \& S.S. Larsen 32754 (AAU, BKF [SN050596], K]); Waeng district, Bala-Hala, 28 Sep 1997, C. Niyondham 5182 (BKF [SN120831, SN120832]), Bala-Hala, Klong Ai Kading, 50 m, 21 Feb 2003, C. Niyondham \& P. Puudjaa 7079 (BKF [SN196475, SN196476]). Patthalung province: See Bahn Poto district, Kao Boo-Kao Yeh National Park, Riang Tong falls, 150 m, 25 Sep 1986, J.F. Maxwell 86-743 (BKF [SN095484]). Ranong province: Kapur, Klong Naka, 13 Nov 1973, T. Santisuk 574 (BKF [SN050595, SN 207019]). Surat Thani province: Ban Na San, 13 Oct 1955, S. Phengnaren 504 (BKF [SN050592]). Trang province: Na Yong district, Kao Chong, $7^{\circ}$ $33^{\prime} \mathrm{N}$, 99 $48^{\prime} \mathrm{E}, 125 \mathrm{~m}$, Jan 2001, S. Davies \& A. Sinbumroong 2001-016 (A, BKF [SN157036]). SE Thailand. Chonburi province: Khaokhieo open zoo, 9 Dec 2000, C. Phengklai 12900 (BKF [SN129167]). Trat province: Ko Kut district, 2 Dec 2006, C. Phengklai et al. 15466 (BKF [SN163846, SN163847]). SW Thailand. Kanchanaburi province: Sangklaburi district, Toong Yai Naresuan Wildlife Reserve, 450 m, 11 Oct 1993, J.F. Maxwell 93-1210 (BKF [SN186798, SN187666]). Uthaithani province: no specific locality, $450 \mathrm{~m}$, 13 Feb 1991, T. Santisuk et al. 249 (BKF [SN197931, SN197932]). Vietnam. Cochinchine (S Vietnam). No locality, 1862-1866, C. Thorel 853 (P [P03937356]). Bienhoa province: Mt. Nui Chua Chan, $300 \mathrm{~m}$ asl, 10 Jan 1928, M. Poilane 14496 (VNM [VNM00011997]), 200-300 m asl, 24 Aug 1931, M. Poilane 19395 (VNM [VNM00012000, VNM00013579]), 200-800 m asl, 10 Jan 1914, F. Fleury in A. Chevalier 29912 (P [P03937347, P03937348, P03937354, P04605437]). Gia Dinh province: Thu dau mot, no date, E. Lefèvre 289 (P [P03937355]), 1862-1866, C. Thorel 1234 (BO [BO-1323143], P [P03937357, P03937358]), Thu dau mot, R. Bung, Sep 1874, L. Pierre 3240 (P [P03937303, P03937306, P04951059]). Hatien province: Phuquoc, $30 \mathrm{Dec}$ 1919, M. Poilane 897 (VNM [VNM00011994]); Iles de Poulo Condor, Sep 1876, J. Harmand 932 (P [P03937308], VNM [VNM00011995]), Condor, Oct 1876, J. Harmand 1918 (P [P03937307]). Tonkin (N Vietnam). No locality, no date, H. Bon s.n. (BO (BO-1323144]), H. Bon $6188 \quad$ (P [P03937341, $\mathrm{P} 03937342]), \quad H . \quad B o n ~ 6201$ (P [P03937345, P03937346]). Backan province: Sep 1919, P. Eberhardt 4618 (P [P03937309], VNM [VNM00011996]). Ha-coi: Taai Wong Mo Shan, near Chuk-phai, 3 May-22 Jun 1939, W.T. Tsang 29044 (A, SING [SING0192948]). Yen Khe
Trung: Do-thong, 12 Nov 1882, H. Bon 1831 (P [P03937343, P03937344]).

Notes. Pitard (1924) maintained both names, but $C$. siamense as a poorly known taxon. Under his enumeration of Canthium glabrum, Craib (1932) stated: "C. siamense, Pitard... which is still represented by the type collection only... is, so far as the material goes, too near $C$. glabrum as interpreted here".

\section{Dibridsonia K.M.Wong, genus novum .}

Type species: Dibridsonia conferta (Korth.) K.M.Wong

Diagnosis. This new genus was previously placed with Canthium Lam. but differs from Canthium s.s. in being arborescent (not scrambling or climbing) in habit and not developing supernumerary axillary buds, axillary spines or axillary short-shoots ('brachyblasts') as in Canthium s.s. It resembles Cyclophyllum Hook.f. and Pyrostria Comm. ex Juss. in lacking a ring of deflexed hairs at the corolla throat, and instead has dense flexuous-suberect moniliform hairs. It differs from both Cyclophyllum and Pyrostria in its stigma base that is slightly recessed, and in its pyrene form which has a rounded ridge-like apical-dorsal crest reaching halfway down to the base with two lateral sloping shoulder-like protrusions (both Cyclophyllum and Pyrostria have solid stigmas, and their pyrenes are plano-obovoid without conspicuous apical-dorsal crests or shoulder-like protrusions).

Trees. Stipules triangular-ovate, with a slight to pronounced median keel prolonged into an apical cusp or lobe. Leaves opposite and decussate on vertical stem axes but distichous on lateral (horizontal) branches; frequently with pit-domatia in the axils of secondary veins. Inflorescences axillary on lateral branches, pedunculate, subumbellate, bracts small and inconspicuous. Flowers functionally unisexual; corolla subrotate or broadly funnel-shaped, glabrous outside, throat with a continuous dense band of erect-spreading (becoming flexuous-crisped) moniliform hairs, the tube around the same length as the lobes, inside without a ring of stiff deflexed hairs just below the throat, corolla lobes spreading in the open flower; stamens alternate with the corolla lobes and not longer than the corolla throat hairs, anthers ovate with broad connective, suberect to spreading, inserted on short filaments at the throat; style glabrous or pubescent, stigma globose to clubshaped, with a slight basal recess; ovary with 2 (rarely 5) locules, each locule with a solitary ovule inserted near the upper part. Fruits obovate to obcordate-compressed (rarely subglobose and 


\section{Key to species of Dibridsonia}

1. Leaves drying dark brown, with 5-7 pairs of secondary veins that loop conspicuously near the leaf margin. Fruits 13-20 mm long, on pedicels 10-18 $\mathrm{mm}$ long 3. D. oblongifolia

Leaves drying pale greenish brown, with 3-4 pairs of secondary veins that fade near the leaf margin Fruits not exceeding $\mathrm{ca} .10 \mathrm{~mm}$ long, on short pedicels not exceeding $5 \mathrm{~mm}$ long .... 2

2. Leaves with 3-4 pairs of secondary veins impressed on the upper leaf surface and conspicuous pit-domatia in their axils with the midrib on the lower surface. Fruits obovoid, 2-locular, with 1-2 pyrenes 1. D. conferta

Leaves with 3 pairs of secondary veins flat to raised on the upper leaf surface and without conspicuous domatia in vein axils on the lower surface. Fruits subglobose and 5-lobed, 5-locular, with 5 pyrenes 2. D. culionensis

5-lobed); pyrenes obovoid-compressed, ventrally plane, dorsally with a rounded ridge-like crest reaching to only halfway to the base, laterally with two rounded sub-apical extensions ('shoulders') sloping downwards, verrucose or minutely tuberculate. Seeds one in each pyrene.

Distribution. West Malesia and the Philippines; three species.

Etymology. The genus honours Diane $M$. Bridson, whose research on the taxonomy of the Canthium complex at the Royal Botanic Gardens, Kew, was both illuminating and inspiring.

1. Dibridsonia conferta (Korth.) K.M.Wong, comb. nov. (Fig. 7, 8)

Basionym: Canthium confertum Korth., Nederl. Kruidk. Arch. 2(2) (1851) 235. - Type: P.W. Korthals s.n., Borneo, G. Pamatton (lectotype A [A00092452], here designated; possible isolectotypes K [K000763635, K000763636], L [L0000158, L0000159, L0000160, L0000161, L0000162, L0000163, L0000164]).

Plectronia viridis Merr., Philipp. J. Sci. 1, Suppl. (1906) 131. - Type: E.D. Merrill 3945, Luzon, Bataan Province, Mt Mariveleo (holotype PNH, probably destroyed; isotypes K [K000763616], US [US00138321]).

Plectronia leytensis Merr., Philipp. J. Sci., C 8 (1913) 49. Canthium leytense (Merr.) Merr., Philipp. J. Sci., C 35 (1928) 8. -Type: M. Ramos Bur. Sci. 15383, Leyte, Dagami, Aug 1912 (holotype PNH, probably destroyed; isotypes K [K000763621], P [P00836750]).

Note. In his protologue, Korthals records "Crescit ad montem Pamatton, Poeloe-Lampei: Borneo." A series of Korthals' collections of this species is available, mostly at $\mathrm{L}$, but the A sheet is the only one with the locality written in Korthals' hand; this is taken as lectotype here.
Other specimens examined. Borneo. Brunei Darussalam. Belait: Andulau F.R., 2 May 1957, P.S. Ashton S 5944 (BO, S); Bukit Puan, 17 May 1957, P.S. Ashton 57887 (SING [SING0189271]). Temburong: Bangar-Batu Apas road, 30 Mar 1957, G.H.S. Wood SAN 17094 (BO). Indonesia. East Kalimantan: Sungei Bloeoe, 1896-97, Jaheri 1566 (BO). Malaysia. Sabah: Balambangan Island, 13 Sep 1927, C.B. Kloss SFN 19288 (BO, SING); Danum Valley, 14 May 1989, C.E. Ridsdale 2014 (SAN), 31 May 1989, C.E. Ridsdale 2063 (SAN); Gunong Silam, 14 Apr 1992, C. Puff \& R. Buchner 920414-1/5 (SAN); Kota Kinabalu, Pulau Gaya, 15 Apr 1977, B.C. Stone et al. SAN 86835 (KEP [KEP208624], L, SAN, SAR, SING); Mount Kinabalu, Mesilau River, $5000 \mathrm{ft}$ asl, 9 Apr 1964, W.L. Chew \& E.J.H. Corner RSNB 4883 (SAN, SING); Lahad Datu, Sapong Ayer, 5 Mar 1963, Muin Chai SAN 33356 (KEP [KEP208394], SAN); Ranau, Tinompok, $4500 \mathrm{ft}$ asl, 17 Nov 1962, $P$. Badak SAN 32380 (KEP [KEP208438]); Sandakan, Sepilok F.R., 19 Feb 1955, G.H.S. Wood A 2875 (A, BRI, K, KEP, L, SING [SING0189367]), Sepilok Laut F.R., 4 Mar 1978, Termiji \& Paul SAN 85491 (SAN); Semporna, Selangan F.R., 22 Sep 1968, B. Sindin SAN 63821 (SAN, SING [SING018923]); Tambunan, Gunong Trus Madi, 12 Aug 1988, Fidilis SAN 25468 (SAN); Tawau, Tawau Hills F.R., 6 Jul 1974, G. Aban \& P. Minjulu SAN 79667 (SAN, SING [SING0189224]); Telupid, Pinangah, Ulu Sungei Melikop, 30 May 1985, Dewol \& Langkap SAN 109190 (SAN, SING [SING0189818]). Sarawak: Marudi, Tinjar, Ulu Dapoi, 7 Apr 1965, Sibat anak Luang S 22982 (A, K, L, SAN, SING [SING0189243]); Miri, Bukit Lambir, 8 Jul 1962, Ilias Paie S 16623 (K, L, SAN, SAR, SING [SING0189244]); Serian, Sabal F.R., 17 Jun 1960, F.G. Nahar S 12694 (A, K, L, SAN, SAR, SING [SING0189297]); Similajau N.P., Sungei Likau, 7 May 1990, Othman et al. $S$ 59027 (K, KEP [KEP68941], L, MO, SAN, SAR). Malay Peninsula. Malaysia. Johor: Gunong Le- 

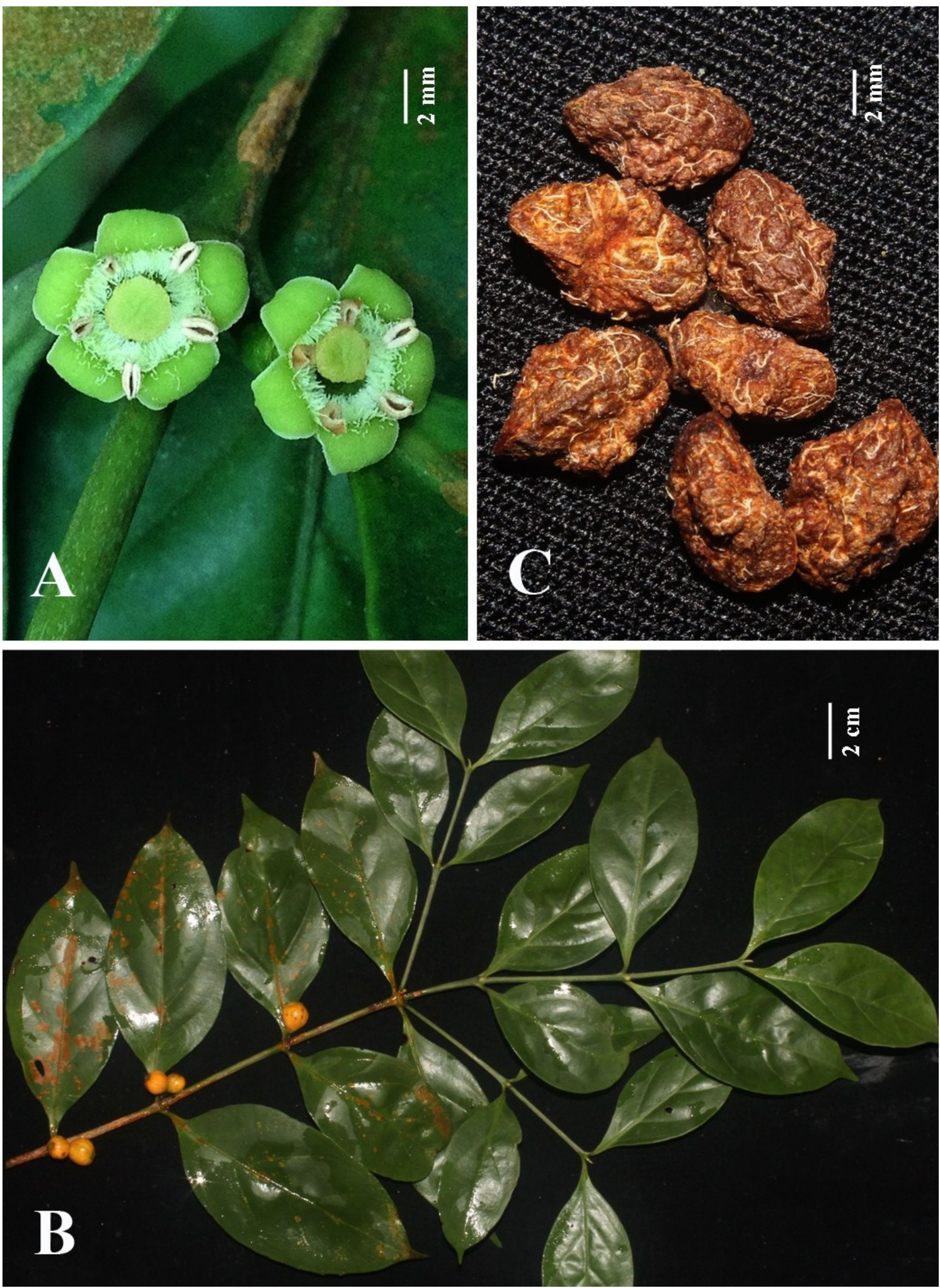

Fig. 7. Dibridsonia conferta.. A. Female flowers showing spreading anthers (empty) and broadly 2-lobed stigmas, with a continuous ring of pale moniliform hairs at the corolla throat. B. Fruiting branch. C. Pyrenes with characteristic verrucose surface. Photos by X.Y. Ng. 


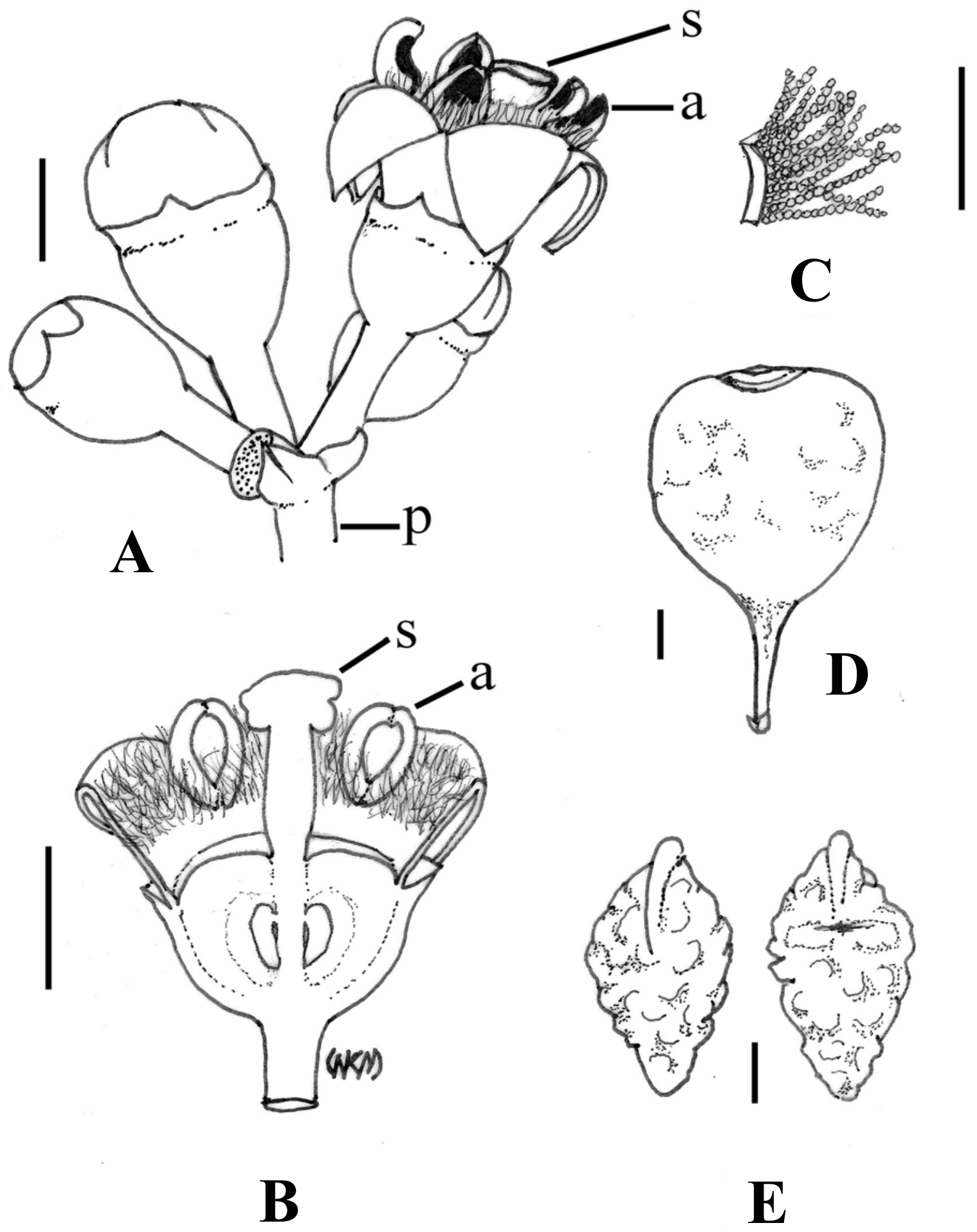

Fig. 8. Dibridsonia conferta. A. Inflorescence with one flower removed (stippled surface). B. Longitudinal section through female flower, showing band of moniliform hairs at the corolla throat. C. Corolla fragment bearing moniliform hairs. D. Fruit. E. Pyrene, dorsal (left) and ventral views. a, empty anther; p, peduncle; $\mathrm{s}$, stigma. Scale bars represent $2 \mathrm{~mm}$, except C (1 mm). [A \& B from Wong s.n., MacRitchie Reservoir forest; C \& D from Samsuri SA 1363 (SING)]. Drawn by K.M. Wong. 
dang, 26 Nov 1971, H.S. Loh FRI 19217 (KEP, SING [SING0189413]); Jason Bay, Sungei Tuanseh, 13 Mar 1966, J. Sinclair SFN 10867 (E, FI, G, K, L, SING [SING0189418]); Mersing, Pulau Setindan, 15 Aug 1935, Corner SFN 29770 (SING [SING0189414]); Sungai Kayu, 18 Mar 1937, Henderson \& Kiah SFN 32426 (BKF [SN125132], KEP, SING [SING0189419]); Ulu Sebol F.R., 6 Feb 1980, Vethevelu FRI 25295 (KEP, SING [SING0189499]). Kelantan: Gunong Stong, 1000 $\mathrm{ft}$ asl, 13 Oct 1935, Symington KEP 37830 (SING [SING0189410]); Ulu Sat F.R., 2 Feb 1970, Kochummen FRI 2542 (KEP [KEP208355]). Melaka: Merlimau, 19 Apr 1886, V.M. Alvins s.n. (SING [SING0189411]). Pahang: Bentong, Raka Hill F.R., 20 Feb 1972, Kochummen FRI 16654 (KEP [KEP208352]); Bukit Taun, 22 Oct 1897, H.W. Lake \& H.J. Kelsall s.n. (SING [SING0189417]); Genting Highlands road, 13 Dec 1974, K.M. Kochummen FRI 23049 (KEP, SING [SING0189478]); Tahan River, 1891, Ridley 2245 (SING [SING0189255]). Penang: Penang Hill, 10 Jan 1918, Haniff \& Nur SFN 3021 (BO, KEP, SING), Moniot's Road, $1500 \mathrm{ft}$ asl, Sep 1901, Curtis 3672 (SING [SING0189412, SING0189421]). Selangor: Kuala Lumpur, Weld Hill Res., date unclear, Ahmad KEP 4577 (SING [SING0189420]). Singapore. Changi, Feb 1894, H.N. Ridley 5910 (SING [SING0019991]); Labrador Nature Reserve, open cliffs, 15 Feb 1982, J.F. Maxwell 8241 (BKF [SN124968, SN124969], SING [SING0019957]); MacRitchie Reservoir, 9 Dec 1976, M. Shah \& J.F. Maxwell 3962 (SING [SING0019968]), Lornie Trail, 9 Dec 2003, S. Lee et al. MRR 9 (SING [SING0050008]); Pulau Tekong, 1890, H.N. Ridley $489 X$ (last digit missing) (SING [SING0019958]); Pulau Ubin, Sep 2008, I. Ali SING 2008-370 (SING [SING0146646]); Woodland, Kranji, 7 Jan 1890, H.N. Ridley 1895 (SING [SING0019970, SING0019977]), Kranji, 1897, H.N. Ridley 11263 (SING [SING0019954]).

2. Dibridsonia culionensis (Elm.) K.M.Wong, comb. nov.

Basionym: Lasianthus culionensis Elm., Leafl. Philipp. Bot. 1 (1906) 11. Plectronia culionensis (Elm.) Merr., Enum. Philipp. Fl. Pl. 3 (1923) 535. Canthium culionense (Elm.) Merr., Philipp. J. Sci. 35 (1928) 8. - Type: E.D. Merrill 615, Culion, Halsey, Dec 1902 (holotype PNH, probably destroyed; isotype SING [SING0058335]).

3. Dibridsonia oblongifolia (Quisumb. \& Merr.) K.M.Wong, comb. nov.

Basionym: Canthium oblongifolium Quisumb. \& Merr., Philipp. J. Sci. 37 (1928) 200. - Type: G.E.Edaño Bur. Sci. 46109, Panay, Capiz, Oct \& Nov 1925 (holotype PNH, probably destroyed; isotypes A [A00092466], K [K000763620], NY

\section{[NY00130996], US [US00138301]).}

Excluded taxon. The name Plectronia glandulosa Merr. (Merrill 1918: 365) has been associated with the Canthium confertum alliance. This was supposedly derived from Ixora glandulosa Blanco Fl. Filip. (1837) 61; ed. 2 (1845) 42; ed. 3, 1 (1877) 78 and Merrill (1918) states: "Ixora glandulosa was erroneously reduced by Fernandez-Villar to Canthium confertum Korth., a species unknown from the Philippines. It is certainly identical with the form described by me in 1906 as Plectronia viridis, but Blanco's specific name being the older is here accepted." Merrill (1918) then nominated as an "Illustrative specimen" the collection Merrill: Species Blancoanae No. 897, Luzon, Bataan Province, Mount Mariveles, Mar 1915 (P [P00836623]). But note that Blanco (1837) described a 4-dentate calyx and 4-lobed corolla, so that interpretation of that entity as a member of the Canthium complex becomes difficult and ambiguous. On the other hand, at the MA Herbarium, the specimen Llanos 198 [MA757232] is annotated by E. Quisumbing in Sep 1958 as lectotype of "Canthium glandulosum (Blanco) Merr. (Ixora glandulosa Blanco)"; however, this is a spiny taxon and is correctly Fagerlindia microcarpa (Bartl. ex DC.) Ridsd. Considering all this, combinations putatively based on Ixora glandulosa Blanco are best ignored.

\section{TREE ARCHITECTURE}

We were able to observe tree form in Canthiumera glabra in the Bogor Botanical Gardens and C. robusta and Dibridsonia conferta in Brunei, Peninsular Malaysia and Singapore. Basically, the lateral (axillary) inflorescences have no influence on shoot growth and plant architecture. The form is a relatively simple one with a monopodial orthotropic stem axis bearing opposite and decussate leaves, and producing branches continuously at most nodes at somewhat even spacing.

The branches are monopodial plagiotropic axes bearing opposite leaves distichously (Fig. 9). Primary branches seldom bear flowers directly but, instead, flowering (and fruiting) occurs mostly along secondary and higher-order branch axes (Fig. 9). Branch growth is also continuous. The primary branches survive for a relatively short period and do not attain very large size even at their base, and in older trees the lower branches senesce and fall off in a "self-pruning" manner, eventually and typically forming an erect trunk with pairs of horizontal to distally pendulous, relatively slender branches forming its crown.

This combination of axis behaviour in tree architectural analysis is characteristic of what is 


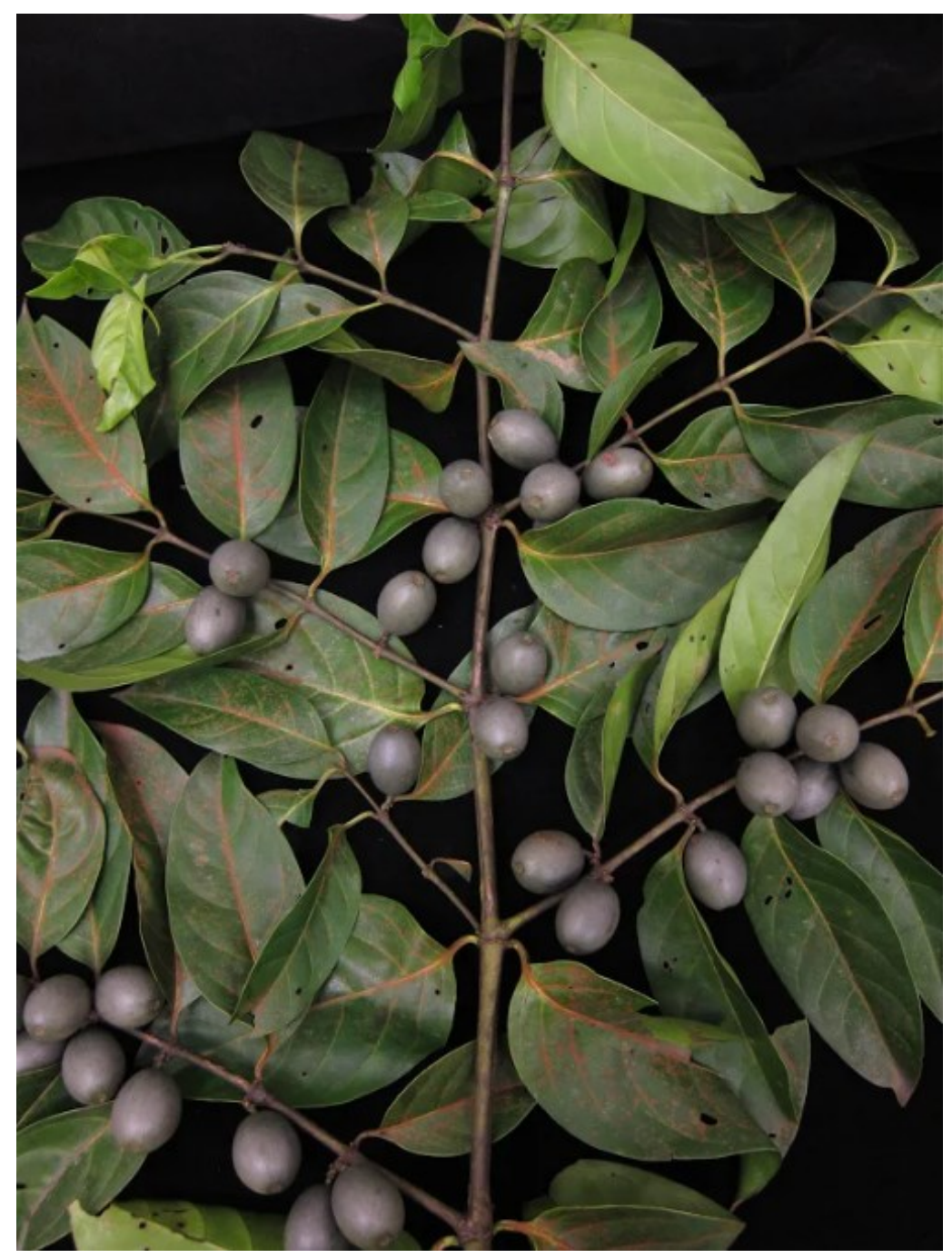

Fig. 9. A fruiting branch of Canthiumera robusta. Note the unequal branch pair at the second node from bottom. Photo by Lim Wei Hao.

known as Cook's model (Hallé et al., 1978). Additionally, the second-order branches along a main (primary) branch are usually in pairs, where alternate pairs have one branch horizontal on one side and the other branch deflexed. The remaining branch pairs each have one branch horizontal on the opposite side and the other deflexed. Deflexed branch members are sometimes abortive or deciduous at an early stage (Fig. 9) (Wong, 1988; 1989). In the Canthium alliance, observed species of Canthiumera, Dibridsonia and Psydrax share this distinctive architecture.

\section{DISPERSAL ECOLOGY}

The fruits of Canthiumera and Dibridsonia are fleshy drupes which contain substantial mesocarp surrounding the pyrenes, and are characteristic of animal-dispersed fruits.

In Canthiumera fruits, the two pyrenes are orientated such that their ventral surfaces face each other, and the angles thus formed by their sharp keel-like crests and lateral shoulders within the endocarp mass (Fig. 10A) probably serve as a deterrent against their mastication by frugivores. Instead, frugivores are likely to either eat only the pulp around the pyrenes and discard the intact pyrenes, or swallow the fruits whole and get rid of the pyrenes later. The keeled, apical-dorsal pyrene crest is likely also a defense against gnawing by seed predators which might gain access secondarily to the discarded bare pyrenes. The elongate embryo within the seed is surrounded by a small amount of endosperm which seems to not be a sufficient reward for seed predators that must first get past the hard, keeled endocarp (pyrene shell) (Fig. 10B). The Canthiumera pyrene structure therefore seems effective for maximizing mesocarp volume and minimizing seed and endosperm volume, in a trade-off between providing a substantial amount of pulp to attract and reward herbivore dispersers, and discouraging 

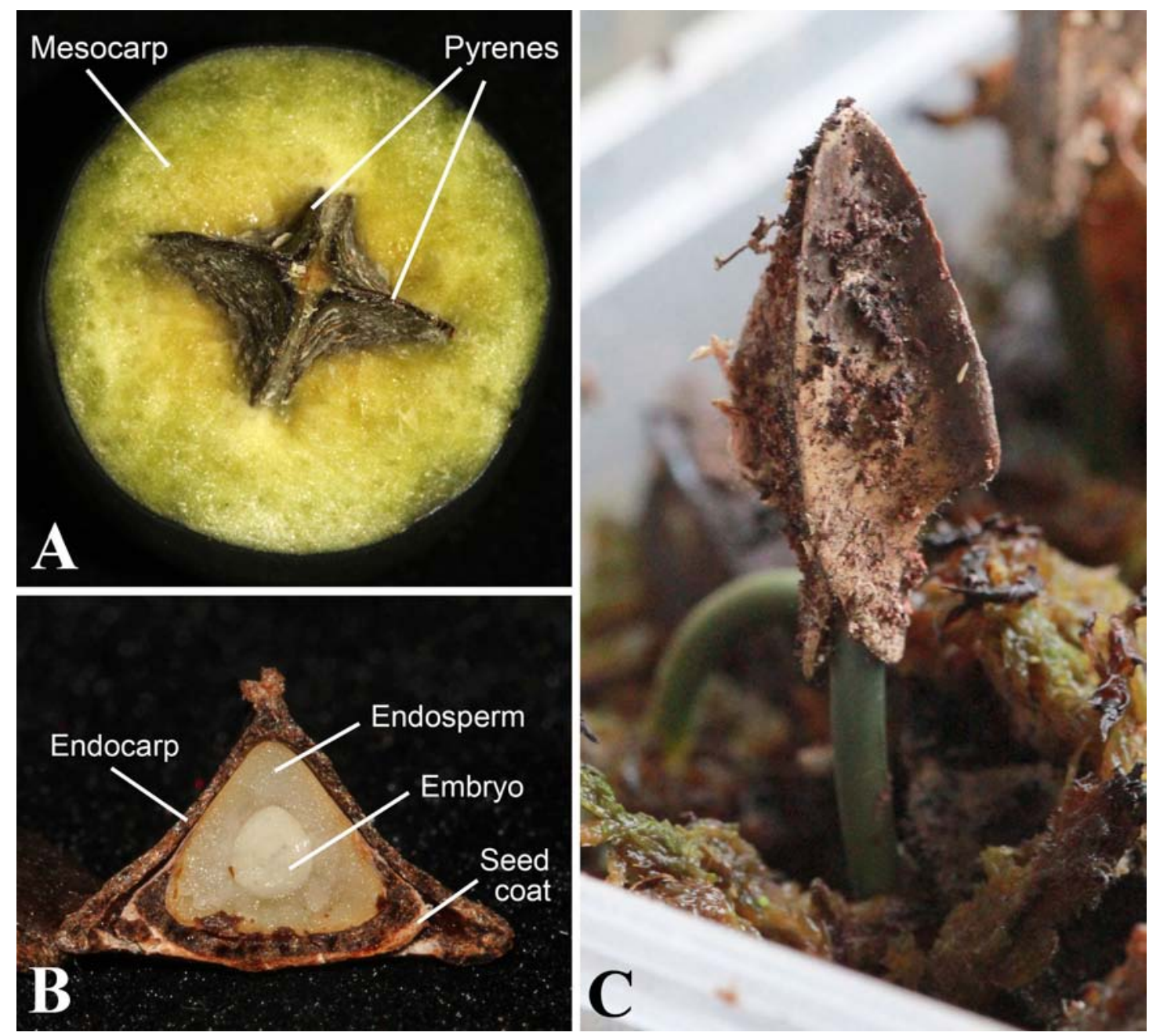

Fig. 10. Canthiumera robusta. A. Transverse section of fresh fruit showing the bases of two ventrally facing pyrenes in a substantial mesocarp matrix. B. Transverse section of pyrene. C. Newly germinated seedling with the radicle having penetrated the preformed germination slit at the pyrene apex and grown downwards, and the green hypocotyl elongating and raising the seed case. Photos by X. Y. Ng.

seed predation and damage.

Canthiumera robusta fruits ripen from green to bluish grey and are relatively large in size. Fruits which ripen to grey are rare, and, in comparison to those which ripen to more common colors such as red or black, they may be a less-preferred resource that is only opportunistically utilized by birds (Duan et al., 2014). Dull-colored fruits are usually known to be primarily mammal-dispersed (Knight \& Siegfried, 1983; Corlett, 1996). In Singapore, Canthiumera robusta fruits are known to be eaten by frugivorous birds with larger gape sizes, such as the red-crowned barbet (Megalaima rafflesii) and common hill myna (Gracula religiosa), which have been observed to peck at the pulp of ripening fruits and then swallow and regurgitate the pyrenes, or swallow the fruits whole and later regurgitate the pyrenes (Bird Ecology Study Group 2016a; 2016b). Canthiumera robusta fruit consumption by primates has not been documented in Singapore, but in Sumatra, it is known to be eaten by the Mentawai langur (Presbytis potenziani) (Hadi, 2012 as 'Canthium glabrum'). Primates are known to deal with seeds in several ways (Corlett \& Lucas, 1990), and it seems possible that they may simply discard the pyrenes of Canthiumera robusta on site. Other arboreal and nocturnal mammals for which fruit color is a less important signal, such as civets, may also have a role in dispersing Canthiumera robusta fruits. The common palm civet (Paradoxurus hermaphrodi$t u s$ ) is known to swallow fruits that are large relative to its gape size, and because it can travel hundreds of meters over the duration of its gutpassage time, and passes out intact seeds, often on bare or open sites such as forest gaps (Ridley, 1930; Nakashima et al., 2010), it could potentially be an important longer-distance disperser of Canthiumera robusta seeds. Furthermore, we have observed that ripe and uneaten Canthiumera robusta fruits which have fallen to the ground will ferment readily in the warm tropical climate 
(suggesting their high sugar content), and we speculate that they could attract yet other dispersal agents such as ground-dwelling mammals to feed on the fermenting pulp, and in doing so move the pyrenes some distance away from the tree.

There is little documentation about Canthiumera glabra dispersal, but it is probably similar to that of C. robusta. Canthiumera siamensis (as 'Canthium glabrum') is reportedly eaten by civets in the Andaman Islands (Akshaya \& Manchi, 2018), and by hornbills and gibbons in Thailand (Kitamura et al., 2002). The latter study reports the fruit colour of Canthiumera siamensis as yellow, which suggests a different dispersal ecology for this species which occurs in seasonal tropical forests. Canthiumera neilgherrensis is very rare, and little is known about its ecology.

In comparison to Canthiumera, Dibridsonia pyrenes are distinctly verrucose and less angular, with sloping lateral shoulders, and a much less prominent crest that is ridge-like rather than keeled, and reaches only halfway to the pyrene base. Despite the lack of a sharp keeled crest, the knobbly, tough endocarp may nevertheless defend well against gnawing by seed predators. The fruits of Dibridsonia do not exceed $2 \mathrm{~cm}$ in length and would fit the gape sizes of many frugivores. The fruits and the pyrenes are presumably easy to swallow whole.

The fruits of Dibridsonia conferta ripen from green to bright orange, which immediately suggests their attractiveness to both birds and arboreal mammals. Dibridsonia conferta (as 'Canthium confertum') has been reported in the diet of long-tailed macaques (Macaca fascicularis) in Singapore (Lucas \& Corlett 1991). The dispersal ecologies of Dibridsonia culionensis and D. oblongifolia are not known.

\section{GERMINATION}

We have observed Canthiumera robusta seed germination in our own trials. Germination of Canthiumera robusta begins with the emergence and downward elongation of the radicle from the preformed germination slit along the apex of the pyrene dorsal crest (Fig. 10C). In our own trials, the time to first germination was 31 days, with a germination period of 60 days, and with $50-60 \%$ germination (based on two trials). Ng (1992) documented the germination period of Canthiumera robusta (as 'Canthium glabrum') as 80 days. The germination of Dibridsonia is not known.

\section{ACKNOWLEDGEMENTS}

We are grateful to the National Parks Board, Singapore, the Herbarium Bogoriense, Research
Center for Biology-LIPI and the Bogor Botanic Garden for support that made this work possible. The Keepers and Curators of the BKF, BO, BRUN, KEP, K, L, SAN, SAR, SING and VNM herbaria are specially thanked for hosting our study visits. We especially thank Dr Joan Pereira (Sandakan) and Dr Kongkanda Chayamarit (Bangkok) for helpful corrections and remarks on the manuscript. Ang Wee Foong and Lim Wei Hao (National Parks Board, Singapore) kindly gave permission for using their images of Canthiumera robusta. Wei Wei Seah (SING Herbarium) and Ian Turner (Flora of Singapore Liaison Officer at the K Herbarium) helped with literature and specimen matters. Pak Harto of the Bogor Botanic Garden kindly helped collect material of Canthiumera glabra. RM acknowledges Prof. Mien A. Rifai, Prof. Tukirin Partomihardjo, Dr. Tatik Chikmawati and Dr. Nunik Sri Ariyanti.

\section{REFERENCES}

AKSHAYA, M. M. \& MANCHI, S. S. 2018. Civets in the limestone caves of Andaman Islands: Notes on the distribution and natural history. Ambient Science 5(1), DOI:10.21276/ ambi.2018.05.1.ga02

ALEJANDRO, G. J. D., MAGDALENO, C. M. M., PACIA, J. A. T., PARAGUISON, L. D., QUIOGUE, K. K. C., WONG, A. E. D., YAYEN, K. M. R. \& ARRIOLA, A. H. 2014. Generic affiliation of Canthium species placed under Pyrostria group B sensu Bridson (Vanguerieae, Rubiaceae) inferred from morphological and molecular data. Bot. Stud. (Taipei) 55: 65, DOI:10.1186/s40529-014-0065 -3 .

ARRIOLA, A. H. \& ALEJANDRO, G. J. D. 2013. A new species of Psydrax (Vanguerieae, Rubiaceae) from Luzon, Philippines. Phytotaxa 149: 27-30.

ARRIOLA, A. H., CAMACHO, P. D., CALARAMO, M. J. A. \& ALEJANDRO, G. J. D. 2015. Pyrostria triflora, a new species of Vanguerieae (Rubiaceae) from Luzon, Philippines. Bangladesh J. Plant Taxon. 22: 55-58.

ARRIOLA, A. H., MEVE, U. \& ALEJANDRO, G. J. D. 2016a. Canthium elmeri Merr. lectotypified and transferred to Pyrostria (Rubiaceae). Ann. Bot. Fennici 53: 216-218.

ARRIOLA, A. H., PARAGUISON, L. D. \& ALEJANDRO, G. J. D. 2016b. Kanapia (Vanguerieae): a new endemic genus of Philippine Rubiaceae. Plant Syst. Evol. DOI: 10.1007/s00606-016-1307-5.

BIRD ECOLOGY STUDY GROUP 2016a. http:// www.besgroup.org/2016/08/08/red-crownedbarbet-swallowing-canthium-glabrum-fruits/. 
Accessed 22 June 2018.

BIRD ECOLOGY STUDY GROUP 2016b. http:// www.besgroup.org/2016/08/05/common-hillmyna-eating-canthium-glabrum-fruits/. Accessed 22 June 2018.

BLANCO, F. M. 1837. Flora de Filipinas. Manila: D. Candido Lopez. 2nd edition 1945; 3rd (Grand) edition 1877.

BLUME, C. L. 1823. Catalogus van eenige der merkwaardigste zoo in-als uit-heemsche gewassen, te vinden in 's lands plantentuin te Buitenzorg. Batavia.

BRIDSON, D. M. 1985. The reinstatement of Psydrax (Rubiaceae, subfamily Cinchonoideae, tribe Vangueriae) and a revision of the African species. Kew Bull. 40: 687-725.

BRIDSON, D. M. 1986. The reinstatement of the African genus Keetia (Rubiaceae subfam. Cinchonoideae, tribe Vanguerieae). Kew Bull. 41: 965-994.

BRIDSON, D. M. 1987. Studies in African Rubiaceae-Vanguerieae: A new circumscription of Pyrostria and a new subgenus, Canthium subgen. Bullockia. Kew Bull. 42(3): 611-639.

BRIDSON, D. M. 1992. The genus Canthium (Rubiaceae-Vanguerieae) in tropical Africa. Kew Bull. 47: 353-401.

CHEN, T., TAYLOR, C. M. \& LANTZ, H. 2011. Psydrax Gaertner. Flora of China 19: 301-302. Beijing: Science Press \& St. Louis: Missouri Botanical Garden.

COODE, M. J. E., DRANSFIELD, J., FORMAN, L. L., KIRKUP, D. W. \& SAID, I. M. 1996. $A$ Checklist of the Flowering Plants and Gymnosperms of Brunei Darussalam. Brunei Darussalam: Ministry of Industry and Primary Resources.

CORLETT, R. T. 1996. Characteristics of vertebrate-dispersed fruits in Hong Kong. $J$. Trop. Ecol. 12: 819-833.

CORLETT, R. T. \& LUCAS, P. W. 1990. Alternative seed-handling strategies in primates: seed-spitting by long-tailed macaques (Macaca fascicularis). Oecologia 82: 166-171.

CRAIB, W. G. 1932. Florae Siamensis Enumeratio. Vol. 2(1). Bangkok: Siam Society.

DAVIS, A. P. \& RUHSAM, M. 2005. Five new combinations and one new name in Rubiaceae from South-East Asia. Blumea 50: 575-578.

DAVIS, A. P., GOVAERTS, R. \& BRIDSON, D. M. 2007. New combinations in Madagascan Vanguerieae (Rubiaceae) for the genera Psydrax, Pyrostria, and Rytigynia. Blumea 52: 139-145.

DUAN, Q., GOODALE, E. \& QUAN, R.-C. 2014. Bird fruit preferences match the frequency of fruit colours in tropical Asia. Scientific Reports 4: 5627, DOI:10.1038/srep05627.

HADI, S., ZIEGLER, T., WALTERT, M., SYAM-
SURI, F., MUHLENBERG, M. \& HODGES, J. K. 2012. Habitat use and trophic niche overlap of two sympatric colobines, Presbytis potenziani and Simias concolor, on Siberut Island, Indonesia. Int. J. Primatol. 33: 218-232, DOI:10.1007/s10764-011-9567-y.

HALLÉ, F., OLDEMAN, R. A. A. \& TOMLINSON, P. B. 1978. Tropical Trees and Forests. An Architectural Analysis. Berlin: SpringerVerlag.

HOOKER, J. D. 1880. The Flora of British India 3 (7): 1-192. London: Spottiswoode \& Co.

IGERSHEIM, A. 1993. Gynoecium development in Rubiaceae-Vanguerieae, with particular reference to the "stylar head"-complex and secondary pollen presentation. Plant Syst. Evol. 187: 175-190.

KING, G. \& GAMBLE, J. S. 1904. Flora of the Malayan Peninsula. Rubiaceae. J. Asiat. Soc. Bengal, Pt. 2, Nat. Hist. 73(3): 57-62.

KITAMURA, S., YUMOTO, T., POONSWAD, P., CHUAILUA, P., PLONGMAI, K., MARUHASHI, T. \& NOMA, N. 2002. Interactions between fleshy fruits and frugivores in a tropical seasonal forest in Thailand. Oecologia 133: 559-572.

KNIGHT, R. S. \& SIEGFRIED, W. R. 1983. Inter-relationships between type, size and colour of fruits and dispersal in Southern African trees. Oecologia 56: 405-412.

KORTHALS, P. W. 1851. Overzigt der Rubiaceën van de Nederlandsch-Oostindische Kolonien Ned. Kruidk. Arch. 2(2): 10-269.

LANTZ, H. \& BREMER, B. 2004. Phylogeny inferred from morphology and DNA data: Characterizing well-supported groups in Vanguerieae (Rubiaceae). Bot. J. Linn. Soc. 146: 257-283.

LUCAS, P. W. \& CORLETT, R. T. 1991. Relationship between the diet of Macaca fascicularis and forest phenology. Folia Primatol. 57: 201-215.

MAHYUNI, R., CHIKMAWATI, T., ARIYANTI, N. S. \& WONG, K. M. 2018. The Psydrax dicoccos complex (Rubiaceae) in Malesia, with three new species. Floribunda 5(8): 322-331.

MCNEILL, J., BARRIE, F. R., DEMOULIN, V. W. R., GREUTER, W., HAWKSWORTH, D. L., HERENDEEN, P. D., KNAPP, S. \& MARHOLD, K. (Eds.). 2012. International Code of Nomenclature for Algae, Fungi, and Plants (Melbourne Code). Koeltz Scientific Books.

MERRILL, E. D. 1918. Species Blancoanae. A Critical Revision of the Philippine Species of Plants described by Blanco and by Llanos. Manila: Bureau of Science.

MERRILL, E. D. 1921. A Bibliographic Enumeration of Bornean Plants. J. Straits Br. Roy. Asiat. Soc., Spec. No. Singapore: Fraser \& 
Neave.

MIQUEL, F. A. W. 1857. Flora van Nederlandsche Indië. Vol. 2. Leipzig: Fleischer.

MOULY, A. \& JEANSON, M. 2015. Specialization to ultramafic substrates and narrow endemism of Cyclophyllum (Rubiaceae) in New Caledonia: contribution of novel species to the understanding of these singular patterns. Acta Bot. Gallica 162: 173-189.

NAKASHIMA, Y., INOUE, E., INOUEMURAYAMA, M. \& JUMRAFIHA, A. S. 2010. High potential of a disturbance-tolerant frugivore, the common palm civet Paradoxurus hermaphroditus (Viverridae), as a seed disperser for large-seeded plants. Mammal Study 35: 209-215.

NG, F. S. P. 1992. Manual of Forest Fruits, Seeds and Seedlings. Forest Research Institute Malaysia, Kuala Lumpur.

PITARD, J. 1924. Canthium, Rubiaceae. In: GAGNEPAIN, F., LECOMTE, H. \& HUMBERT, H. (Eds.). La Flore générale de l'Indochine Vol. 3. Paris: Masson. Pp. 20-442 (Canthium pp. 290-300).

PUFF, C. \& WONG, K. M. 2005. Perakanthus (Rubiaceae-Vanguerieae), a rare Malay Peninsula endemic: generic delimitation, status and affinities. Sandakania 16: 29-47.

RAZAFIMANDIMBISON, S. G., LANTZ, H. \& BREMER, B. 2007. New combinations and names in Peponidium and Pyrostria (Rubiaceae, Vanguerieae). Novon 17: 516-521.

RAZAFIMANDIMBISON, S. G., LANTZ, H., MOULY, A. \& BREMER, B. 2009.
Evolutionary trends, major lineages, and new generic limits in the dioecious group of the tribe Vanguerieae (Rubiaceae): insights into the evolution of functional dioecy. Ann. Missouri Bot. Gard. 96: 161-181.

RIDLEY, H. N. 1923. The Flora of the Malay Peninsula. Vol. 2. London: L. Reeve \& Co.

RIDLEY, H. N. 1930. The Dispersal of Plants Throughout the World. L. Kent: Reeve \& Co.

RIDSDALE, C. E. 1998. Psydrax. In: DASSANAYAKE, M. D. \& CLAYTON, W. D. (Eds.). A Revised Handbook to the Flora of Ceylon. Rotterdam: A. A. Balkema Publishers.

THIERS, B. [continuously updated]. Index Herbariorum: A Global Directory of Public Herbaria and Associated Staff. New York Botanical Garden's Virtual Herbarium. http:// sweetgum.nybg.org/science/ih/

WONG, K. M. 1988. The Arborescent Rubiaceae of Malaya. Bound and distributed by the author (copies in the libraries of the Arnold Arboretum of Harvard Univ., Kew Herbarium, Leiden Herbarium and Singapore Botanic Gardens).

WONG, K. M. 1989. Psydrax Gaertn. (Rubiaceae). In: Ng, F.S.P. (Ed.) Tree Flora of Malaya. A Manual for Foresters. Vol. 4. Selangor, Malaysia: Longman Malaysia Sdn Berhad.

WONG, K. M. \& MAHYUNI, R. 2018. Flora of Singapore Precursors, 2. A new species and two new combinations in Psydrax (Rubiaceae: Vanguerieae) for West Malesia. Reinwardtia 17 (1): 77-84. 


\section{INSTRUCTION TO AUTHORS}

Scope. Reinwardtia is a scientific regular journal on plant taxonomy, plant ecology and ethnobotany published in June and December. Manuscript intended for a publication should be written in English.

Titles. Titles should be brief, informative and followed by author's name and mailing address in oneparagraphed.

Abstract. English abstract followed by Indonesian abstract of not more than 250 words. Keywords should be given below each abstract.

Manuscript. Manuscript is or iginal paper and represent an article which has not been published in any other journal or proceedings. The manuscript of no more than 36 pages by using Times New Roman 11, MS Word for Windows of A4 with double spacing, submitted to the editor through Reinwardtia online journal system and < reinwardtia@mail.lipi.go.id>. New paragraph should be indented in by 5 characters. For the style of presentation, authors should follow the latest issue of Reinwardtia very closely. Author(s) should send the preferred running title of the article submitted. Every manuscript will be sent to two blind reviewers.

Identification key. Taxonomic identification key should be prepared using the aligned couplet type.

Nomenclature. Strict adherence to the International Code of Nomenclature is observed, so that taxonomic and nomenclatural novelties should be clearly shown. English description for new taxon proposed should be provided and the herbaria where the type specimens area deposited should be presented. Name of taxon in taxonomic treatment should be presented in the long form that is name of taxon, author's name, year of publication, abbreviated journal or book title, volume, number and page.

Map/line drawing illustration/photograph. Map, line drawing illustration, or photograph preferably should be prepared in landscape presentation to occupy two columns. Illustration must be submitted as original art accompanying, but separated from the manuscript. The illustration should be saved in JPG or GIF format at least 350 pixels. Legends or illustration must be submitted separately at the end of the manuscript.

References. Bibliography, list of literature cited or references follow the Harvard system as the following examples.

Journal : KRAENZLIN, F. 1913. Cyrtandraceae novae Philippinenses I. Philipp. J. Sci. 8: 163-179.

MAYER, V., MOLLER, M., PERRET, M. \& WEBER, A. 2003. Phylogenetic position and generic differentiation of Epithemateae (Gesneriaceae) inferred from plastid DNA sequence data. American J. Bot. 90: 321-329.

Proceedings : TEMU, S. T. 1995. Peranan tumbuhan dan ternak dalam upacara adat "Djoka Dju" pada suku Lio, Ende, Flores, Nusa Tenggara Timur. In: NASUTION, E. (Ed.). Prosiding Seminar dan Lokakarya Nasional Etnobotani II. LIPI \& Perpustakaan Nasional: 263-268. (In Indonesian).

SIMBOLON, H. \& MIRMANTO, E. 2000. Checklist of plant species in the peat swamp forests of Central Kalimantan, Indonesia. In: IWAKUMA, T., INOUE, T., KOHYAMA, T., OSAKI, M., SIMBOLON, H., TACHIBANA, H., TAKAHASHI, H., TANAKA, N., YABE, K. (Eds.). Proceedings of the International Symposium on: Tropical Peatlands. Pp.179 - 190.

Book : RIDLEY, H. N. 1923. Flora of the Malay Peninsula 2. L. Reeve \& Co. Ltd, London.

Part of Book : BENTHAM, G. 1876. Gesneriaceae. In: BENTHAM, G. \& HOOKER, J. D. Genera Plantarum 2. Lovell Reeve \& Co., London. Pp. 990-1025.

Thesis : BAIRD, L. 2002. A Grammar of Kéo: An Austronesian Language of East Nusantara. Australian National University, Canberra. [PhD. Thesis].

Website : http://www.nationaalherbarium.nl/fmcollectors/k/KostermansAJGH.html. (Accessed 15 February 2012). 


\section{Reinwardtia}

Published by Herbarium Bogoriense, Botany Division, Research Center for Biology, Indonesian Institute of Sciences

Address: Jln. Raya Jakarta-Bogor Km. 46 Cibinong 16911, P.O. Box 25 Cibinong

Telp. (+62) 21 8765066; Fax (+62) 218765062

LIPI

Email: reinwardtia@mail.lipi.go.id

\section{REINWARDTIA Author Agreement Form}

Title of article

Name of Author(s) :

I/We hereby declare that:

- $\mathrm{My} / \mathrm{Our}$ manuscript was based on my/our original work.

- It was not published or submitted to other journal for publication.

- I/we agree to publish my/our manuscript and the copyright of this article is owned by Reinwardtia.

- We have obtained written permission from copyright owners for any excerpts from copyrighted works that are included and have credited the sources in our article. 



\section{REINWARDTIA}

Vol. 17. No. 2. 2018

CONTENTS

LAODE ALHAMD. Ecological study of the arrowroot (Tacca leontopetaloides (L.) Kuntze) at Karimunjawa National Park (KNP), Central Java

YASPER MICHAEL MAMBRASAR \& PRIMA W. K. HUTABARAT. Rhododendron meagaii, a new species of Rhododendron subgenus Vireya (Ericaceae) from Papua, Indonesia

K. M. WONG, RIDHA MAHYUNI, XIN YI NG \& LOUISE NEO. Flora of Singapore Precursors, 8. Systematy of the new Southeast Asian genera Canthiumera and Dibridsonia (Rubiaceae: Vanguerieae), with notes on plant architecture and reproductive ecology

ANDREW POWLING. An assessment of present plant diversity on the Natewa Peninsula, Vanua Levu, Fiji 125

ASEP SADILI, KUSWATA KARTAWINATA, HERWASONO SOEDJITO \& EDY NASRIADI SAMBAS. Tree species diversity in a pristine montane forest previously untouched by human activities in Foja Mountains, Papua, Indonesia

Reinwardtia is a LIPI accredited Journal (792/AU3/P2MI-LIPI/04/2016)

http://e-journal.biologi.lipi.go.id/index.php/reinwardtia

Herbarium Bogoriense

Botany Division

Research Center for Biology - Indonesian Institute of Sciences

Cibinong Science Center

Jln. Raya Jakarta - Bogor, Km 46

Cibinong 16911, P.O. Box 25 Cibinong

Indonesia 